\title{
Catalytic steam reforming of biomass tar: Prospects and challenges
}

\author{
Guoqing Guan ${ }^{1,2^{*}}$, Malinee Kaewpanha ${ }^{1}$, Xiaogang $\mathrm{Hao}^{3}$, Abuliti Abudula ${ }^{1,2}$ \\ ${ }^{1}$ Graduate School of Science and Technology, Hirosaki University, 1-Bunkyocho, \\ Hirosaki 036-8560, Japan \\ ${ }^{2}$ North Japan Research Institute for Sustainable Energy (NJRISE), Hirosaki University, \\ 2-1-3, Matsubara, Aomori 030-0813, Japan \\ ${ }^{3}$ Department of Chemical Engineering, Taiyuan University of Technology, Taiyuan
} 030024, China

*Corresponding author. Tel.: +81-17-762-7756; Fax: +81-17-735-5411

E-mail address: guan@hirosaki-u.ac.jp (G. Guan) 


\section{Abstract}

Tar is unavoidable by-product during biomass gasification process. Catalytic steam reforming of tar to syngas is a promising way for the removal of tar from the gas products. However, the key issue for this way is catalyst development. To date, the developed catalysts always have advantages and disadvantages: nickel-based catalysts have high activity, but they are easily deactivated by coking; noble metal based catalysts have high catalytic activity, long-term stability and high carbon deposition resistance, but they are expensive; other transition metal catalysts such as $\mathrm{Fe}, \mathrm{Co}$ and $\mathrm{Cu}$ exhibit a good performance, but they are also deactivated easily by carbon deposition in the case of high heavy-tar content in the tar; alkali metal catalysts also have high catalytic activity for tar reforming, but they are easy to be evaporated with the generated gases; natural catalysts have been widely applied for the steam reforming of tar due to its inexpensive, abundant and disposable, but their catalytic activities are lower than those man-made ones, and especially have low mechanical strength, making them not suitable to be used in fluidized bed reactor; zeolite is suggested to be a good catalyst support due to its high thermal/hydrothermal stability, high resistance to sulfur compounds, and easy to be regenerated; biomass char has been used as the catalyst or catalyst support in the steam reforming of tar due to its low cost and its natural production inside the biomass gasifier; even biomass ash now is considered to be a good catalyst for tar removal. In this review, to get better understanding of the mechanism of catalytic steam reforming of tar derived from biomass, tar formation, tar properties and catalytic reaction mechanism are also introduced, and prospects and challenges are summarized.

Keywords: Biomass; tar; gasification; catalyst; steam reforming; activity; stability; challenge. 


\section{Contents}

1. Introduction

1.1 Biomass resources

1.2 Biomass energy conversion

1.3 Biomass gasification

1.4 Tar issue

2. Steam reforming of biomass tar

2.1 Tar formation and properties

2.2 Catalytic steam reforming of tar

2.3 Mechanism of catalytic steam reforming of tar

3. The prospects of catalyic reforming of tar

3.1 Nickel-based catalysts

3.2 Non-nickel transition metal catalysts

3.3 Alkali catalysts

3.4 Natural catalysts

3.5 Zeolite catalysts

3.6 Carbon-supported catalysts

4. Conclusions and remarks

Acknowledgements

References 


\section{Introduction}

\subsection{Biomass resources}

Nowadays, energy, environment and economy (3E) issues are three common concerns that should be considered simultaneously. Due to the growth of the world's population, worldwide energy demand is increasing rapidly. To date, fossil fuels are the major energy resources for the world energy requirement. However, they cause global warming and air pollution due to the emission of greenhouse gas and toxic gases and particles. To solve the $3 \mathrm{E}$ issues simultaneously, the utilization of new energy resources such as solar, wind, tide, geothermal and biomass, which are abundant, low carbon emission and environmentally friendly, is becoming more and more important. Among these new energy resources, it should be noted that only biomass is the real renewable energy source which can provide stable power as fossil fuels. For instances, the use of solar energy is limited in the day time; the use of geothermal energy may let toxic chemicals under the earth erupt to the atmosphere and the use of wind energy needs strong and stable wind, and simultaneously generate noise problem. According to the World Energy Outlook 2011, biomass is the fourth world-wide energy resource after coal, petroleum and natural gas (Table 1) and could provide about $14 \%$ of the world's energy consumption [1]. Moreover, compared with fossil fuels, the use of biomass as fuel is a carbon neutral process since the produced carbon dioxide from biomass utilization process can be captured via photosynthesis during the growth of biomass. Thus, the utilization of biomass energy can result in both the reduction of greenhouse gas emission and the replacement of non-renewable energy resources [2-6].

Table 1. World primary energy demand (Mtoe) [8]. 
Biomass can be defined as any organic materials derived from plants or animals which can be divided into two main groups: (1) Virgin biomass (2) Waste (Fig. 1) [2].

\subsection{Biomass energy conversion}

Biomass is the renewable source of carbon which can be converted to solid, liquid and gaseous products through various conversion processes. To date, as shown in Fig.2, there are 4 main routes, i.e., direct combustion, physical conversion, biochemical and thermochemical conversions, to convert biomass into various energy such as heat, solid, liquid and gaseous fuels. For biochemical conversions, the biomass is converted into liquid (ethanol, acetone and butanol, hydrogen) or gaseous fuels (methane) by aerobic fermentation or anaerobic fermentation while for thermochemical conversions, the biomass can be converted by four main ways: (1) torrefaction; (2) direct liquefaction; (3) pyrolysis and (4) gasification. Thermochemical conversion technologies have some advantages over biochemical conversion ones. The feedstock for biochemical processes is very limited (rich in starch or sugar) whereas that for the thermochemical processes can include anything. Moreover, thermochemical conversion rate processes is much faster than biochemical one [7].

Fig. 1. Major groups of biomass and their sub classifications $[1,2,7]$.

\subsection{Biomass gasification}


Among all thermochemical conversion technologies, gasification is a promising way to convert biomass energy into gas fuels, called syngas (synthesis gas), which can be widely used for electrical power generation (fuel cells, gas turbine or engine), or as feedstock for the synthesis of liquid fuels and various chemicals [10-12]. Therefore, biomass gasification has attracted the most attention from both industrial and academic researchers due to its advantages. Biomass gasification is a thermochemical conversion process in which carbonaceous substances in biomass are converted into combustible gaseous products in the presence of a gasifying agent (air, steam, oxygen, $\mathrm{CO}_{2}$ or a mixture of these) at high temperatures (generally over $700{ }^{\circ} \mathrm{C}$ to date). The main products of biomass gasification are $\mathrm{H}_{2}, \mathrm{CO}, \mathrm{CO}_{2}, \mathrm{CH}_{4}, \mathrm{H}_{2} \mathrm{O}$, solid carbonaceous residues, ashes, and tars (oils) [12-14]. Biomass gasification process usually undergoes 4 steps as illustrated in Fig.3:

- Drying and Heating of biomass: This step occurs from the start until a temperature of around $200{ }^{\circ} \mathrm{C}$. For gasification, the optimum moisture content in the biomass should be below $15 \%$, and thus, more moisture in the biomass should be evaporated at first by heating.

- Pyrolysis: This step occurs at the temperature ranged from 150 to $900{ }^{\circ} \mathrm{C}$. Hemicellulose, cellulose and lignin in biomass will be decomposed in order into gases with small molecules and volatiles with various molecular weights and char (a solid residue mainly containing carbon). Some volatiles become to liquid after cooled down to room temperature, which is called tar, a black, viscous and corrosive liquid composed of heavy organic and inorganic molecules. 
- Oxidation or partial combustion: This step occurs at a temperature over 700 ${ }^{\circ} \mathrm{C}$. The products of the pyrolysis are partially or completely oxidized with oxygen in air to form $\mathrm{CO}, \mathrm{CO}_{2}$, and $\mathrm{H}_{2} \mathrm{O}$. The oxidation reactions are exothermic which provides heat for the subsequent gasification reactions.

- Reduction or gasification: This step occurs at temperatures over $800{ }^{\circ} \mathrm{C}$, in which the char reacts with gasifying agents such as oxygen and steam, and the final products mainly include $\mathrm{H}_{2}, \mathrm{CO}, \mathrm{CO}_{2}$ and $\mathrm{CH}_{4}$.

Fig. 3. Main processes during biomass gasification.

The main reactions that occur during biomass gasification can be summarized as follows [13]:

$\begin{array}{llr}\text { Boudouard reaction: } & \mathrm{C}+\mathrm{CO}_{2} \leftrightarrow 2 \mathrm{CO} & +172 \mathrm{~kJ} / \mathrm{mol} \\ \text { Stean gasification: } & \mathrm{C}+\mathrm{H}_{2} \mathrm{O} \leftrightarrow \mathrm{CO}+\mathrm{H}_{2} & +131 \mathrm{~kJ} / \mathrm{mol} \\ \text { Hydrogasification: } & \mathrm{C}+2 \mathrm{H}_{2} \leftrightarrow \mathrm{CH}_{4} & -74.8 \mathrm{~kJ} / \mathrm{mol} \\ \text { Oxidation reactions: } & \mathrm{C}+\mathrm{O}_{2} \rightarrow \mathrm{CO}_{2} & -394 \mathrm{~kJ} / \mathrm{mol} \\ & \mathrm{CO}+\mathrm{O}_{2} 5 \mathrm{O}_{2} \rightarrow \mathrm{CO}_{2} & -284 \mathrm{~kJ} / \mathrm{mol} \\ & \mathrm{CH}_{4}+2 \mathrm{O}_{2} \leftrightarrow \mathrm{CO}_{2}+2 \mathrm{H}_{2} \mathrm{O} & -803 \mathrm{~kJ} / \mathrm{mol} \\ & \mathrm{H}_{2}+0.5 \mathrm{O}_{2} \rightarrow \mathrm{H}_{2} \mathrm{O} & -242 \mathrm{~kJ} / \mathrm{mol} \\ & \mathrm{CO}+\mathrm{H}_{2} \mathrm{O} \leftrightarrow \mathrm{CO}_{2}+\mathrm{H}_{2} & -41.2 \mathrm{~kJ} / \mathrm{mol} \\ & & \\ & 2 \mathrm{CO}+2 \mathrm{H}_{2} \rightarrow \mathrm{CH}_{4}+\mathrm{CO}_{2} & -247 \mathrm{~kJ} / \mathrm{mol}\end{array}$




$$
\begin{array}{ccc} 
& \mathrm{CO}+3 \mathrm{H}_{2} \leftrightarrow \mathrm{CH}_{4}+\mathrm{H}_{2} \mathrm{O} & -206 \mathrm{~kJ} / \mathrm{mol} \\
& \mathrm{CO}_{2}+4 \mathrm{H}_{2} \rightarrow \mathrm{CH}_{4}+2 \mathrm{H}_{2} \mathrm{O} & -165 \mathrm{~kJ} / \mathrm{mol} \\
\text { Steam reforming reactions: } & \mathrm{CH}_{4}+\mathrm{H}_{2} \mathrm{O} \leftrightarrow \mathrm{CO}+3 \mathrm{H}_{2} & +206 \mathrm{~kJ} / \mathrm{mol} \\
& \mathrm{CH}_{4}+0.5 \mathrm{O}_{2} \rightarrow \mathrm{CO}+2 \mathrm{H}_{2} & -36 \mathrm{~kJ} / \mathrm{mol}
\end{array}
$$

In these gasification reactions, one important factor to significantly influence on the quantity and quality of the products is the gasifying agent. The use of different gasifying agents results in different reactivity and gas compositions. Various gasifying agents such as air, oxygen, steam, carbon dioxide or their mixtures can be used. The choice of them depends on the desired product gas composition and energy consumption $[14,15]$. Air is the most used gasifying agent owing to its near-zero cost, but the obtained syngas has low heating value due to the dilute effect of the large amount of nitrogen in air. Pure oxygen can produce syngas with higher quality, but the operating cost is high due to energy requirement for the oxygen production [16]. In contrast, steam gasification of biomass can increase the heating value of syngas. In recent years, steam gasification of biomass attracts more and more attentions because it produces a gaseous fuel with relatively higher hydrogen content which can be used in fuel cells and hydrogen engines. However, the composition and properties of the products from the steam gasification of biomass depend on several parameters. Thus, to obtain the desired product gas, the gasification operating conditions need to be optimized.

Biomass consists of cellulose and hemicellulose, lignin and minerals (ash) [17]. These components affect the product composition from the steam gasification of 
biomass. Many researchers carried out gasification of different types of biomass. Hanaoka et al. [18] studied the gasification of two types of biomass: aquatic biomass (gulfweed) and terrestrial biomass (cedar), which have different chemical compositions and ash content, and found that gulfweed obtained a higher conversion to gas compared to that of cedar. This is due to the higher ash content in gulfweed (11.8 wt.\%) and residual alkaline metals in char promoted pyrolysis and char gasification. In our previous study[19], three types of biomass, i.e., brown seaweed, Japanese cedar, apple branch containing different concentrations of alkali and alkaline earth species, and the mix of both of them were gasified with steam in a fixed-bed reactor under atmospheric pressure. The results also indicated that higher gas production yields (especially for $\mathrm{H}_{2}$ and $\mathrm{CO}_{2}$ ) were obtained for brown seaweed than other two types of biomass since the brown seaweed contains much higher ash content and larger amount of alkali and alkaline earth species than terrestrial biomass. Although some compositions in ash can promote the gasification rate, the extremely high amount of ash may cause some disadvantages. Yang et al. [20] co-gasified woody biomass and microalgae in a fluidized bed and found that the high ash content in microalgae ( 9 wt.\%) caused sintering and agglomeration during gasification so that the cogasification was unfavorable for syngas production. Asadullah et al. [21] performed gasification of different biomass in a dual-bed gasifier system and concluded that the carbon conversion to gas and the yields of useful gases such as $\mathrm{CO}, \mathrm{H}_{2}$ and $\mathrm{CH}_{4}$ were dependent on the characteristics of each type of biomass. Lapuerta et al. [22] reported that $\mathrm{K}_{2} \mathrm{O}$ content in biomass ash can play an important role on the gasification performance, since its catalytic effect improved the energy content of produced gas.

Gasification temperature is also a significant operating parameter, which has great 
effect on the gaseous composition and carbon conversion throughout the oxidation and gasification reactions [23]. Yan et al. [24] studied the effect of bed temperature on hydrogen yield and syngas composition. With the increasing of the bed temperature from 600 to $850{ }^{\circ} \mathrm{C}$, the carbon conversion efficiency was obviously increased from 13.16 to $95.78 \%$ and the dry gas yield increased from 0.19 to $2.44 \mathrm{Nm}^{3} / \mathrm{kg}$. Moreover, $\mathrm{H}_{2}$ content was increased significantly from 29.54 to $52.41 \%$. Min et al. [25] investigated the effect of bed temperature $\left(500-850{ }^{\circ} \mathrm{C}\right)$ on tar content and found that the tar yield was decreased with the increasing of temperature. Erkiaga et al. [26] gasified pinewood sawdust in the bed temperature range of $800-900{ }^{\circ} \mathrm{C}$, and observed that the increase in the temperature led to the increasing of $\mathrm{H}_{2}$ content and the decreasing of tar and char yields. Berrueco et al. [27] investigated the gasification properties of two types of biomass (Norwegian spruce and Norwegian forest residues) at $750-850{ }^{\circ} \mathrm{C}$ and found that the increase of temperature resulted in higher gas yield, higher char gasification rate and lower tar formation. From these results, it can conclude that the gasification temperature is the dominant parameter which influences both the amount and compositions of products. Higher gasification temperature produces a syngas rich in hydrogen and carbon monoxide but with small amounts of methane and heavy hydrocarbons. This is because the higher temperature enhances the endothermic steam gasification reactions and Boudouard reaction. Moreover, higher temperature can effectively decompose and convert the tar into lighter gaseous products.

Steam flow rate is another important parameter to influence both product gas compositions and energy input in the steam gasification of biomass $[1,28]$. Generally, the steam flow rate is expressed in term of steam to biomass ratio (S/B), which is defined as the flow rate of the steam fed into the gasifier divided by the biomass flow 
rate. Many researchers have reported that the introduction of a sufficient steam amount leads to the increase of gas yield, especially the increase of hydrogen yield. Xiao et al. [29] studied the catalytic steam gasification of biomass in fluidized bed at low temperature. The effects of catalyst performance, reaction temperature and steam amount on gas yield, gas composition and carbon conversion efficiency were investigated. They found that the carbon conversion, the selectivity of $\mathrm{H}_{2}$ and the energy output were improved by the introduction of steam. The product gas contains lower $\mathrm{CH}_{4}$ and $\mathrm{CO}$ contents due to steam reforming of $\mathrm{CH}_{4}$ and the water-gas shift of $\mathrm{CO}$. However, the $\mathrm{H}_{2}$ yield was increased from 13.9 to $21.3 \mathrm{mmolg}^{-1}$-d.a.f., which is very close to the optimum value of $22.0 \mathrm{mmolg}^{-1}$-d.a.f. at the equilibrium state. Luo et al. [30] investigated the effect of S/B in the range of 0-2.80 on the gasification performance, and observed that the introduction of steam improved the dry gas yield and carbon conversion efficiency but the excessive steam decreased hydrogen content and finally degraded fuel gas quality. They reported that the optimum S/B was 2.10 in which the hydrogen content reaches the maximum, up to $52.7 \%$. Meng et al. [31] also investigated the effect of S/B on product gas distribution and tar formation. The results revealed that with the increasing of S/B from 1.13 to 1.45 at $770{ }^{\circ} \mathrm{C}$, the total tar content was decreased from 10.2 to $7.2 \mathrm{~g} / \mathrm{Nm}^{3}$. They also reported that with the increase in $\mathrm{S} / \mathrm{B}$, the concentrations of $\mathrm{CO}, \mathrm{CH}_{4}, \mathrm{C}_{2} \mathrm{H}_{4}$ and $\mathrm{C}_{2} \mathrm{H}_{2}$ gradually decreased, while the concentration of $\mathrm{H}_{2}$ increased due to the partial oxidation and steam reforming reactions. Lv et al. [32] studied the effects of operating conditions on gas composition and carbon conversion efficiency. In their experiments, the S/B was varied from 0 to 4.04. Their results revealed that the introduction of steam improved the gas quality. With the increase of S/B from 1.35 to 2.70, the contents of $\mathrm{CO}, \mathrm{CH}_{4}$ and $\mathrm{C}_{2} \mathrm{H}_{2}$ decreased 
gradually, whereas $\mathrm{CO}_{2}$ and $\mathrm{H}_{2}$ content increased. From these results, one can conclude that the introduction of steam in gasification process can provide a gaseous product with high content of $\mathrm{H}_{2}$. Moreover, the increase of steam flow rate can decrease char and tar yields since the introduction of steam favors water-gas shift reaction, steam gasification of char, and steam reforming of tar. However, the use of excess steam may cause some disadvantages including high water quantity in the produced gas, which leads to more energy consumption in separation of steam out of the gas product.

\subsection{Tar issue}

Tar formation is one of the major problems during biomass gasification, which can cause the following 3 problems [12]:

- Condensation and subsequent plugging of downstream equipment

- Formation of tar aerosols

- Polymerization into more complex structures

High concentration of tar can lead to unacceptable levels of maintenance for engines and turbines. Especially, tar is harmful to our health because of its carcinogenic character. Tar can be defined as a complex mixture of condensable hydrocarbons, which includes single ring to 5-ring aromatic compounds along with other oxygen-containing hydrocarbons and complex polycyclic aromatic hydrocarbon (PAH) [33].

There are many possible techniques for tar removal. In general, tar removal methods can be classified into physical method using ceramic candle filters or wet scrubber, and thermochemical conversion method using high temperature or using catalyst to convert tar into syngas. In comparison to the physical method which only physically removes tar from gas product, the latter one has received much attention 
because tar can be converted into useful gas product, and increase the overall efficiency of the gasification process [34]. Thermal cracking of tar at high temperature to decompose the large organic molecules to smaller non-condensable gases without catalyst is not attractive because it requires energy and produces soot [35]. In contrast, catalytic conversion of tar can reduce the reaction temperature and more effectively convert tar to useful gases.

Two main approaches are considered for catalytic tar conversion [36]. One is mixing catalyst with the biomass feedstock and in this case, tar can be converted inside the gasifier. The other approach uses a separated reactor located at the downstream of the gasifier and converts tar outside the gasifier. Although the latter one has high effectiveness to remove tar, it is either costly or complex for those small and medium scale systems $[37,38]$.

To date, it is proved that steam reforming of tar, which can be expressed in Eq. (14), is a very attractive technique for tar removal since it can remove tar more effectively and simultaneously convert tar into useful gases $\left(\mathrm{H}_{2}, \mathrm{CH}_{4}\right.$, and $\left.\mathrm{CO}\right)$ [39-41]. Especially, in this process, the produced $\mathrm{CO}$ can react further with the excess steam via water-gas shift (WGS) reaction as shown in Eq. (15) to produce more useful gas like $\mathrm{H}_{2}$ [42].

$\mathrm{C}_{\mathrm{x}} \mathrm{H}_{\mathrm{y}} \mathrm{O}_{\mathrm{z}}+(\mathrm{x}-\mathrm{z}) \mathrm{H}_{2} \mathrm{O} \rightarrow \mathrm{xCO}+[(\mathrm{x}+\mathrm{y} / 2-\mathrm{z})] \mathrm{H}_{2}$

$\mathrm{CO}+\mathrm{H}_{2} \mathrm{O} \leftrightarrow \mathrm{CO}_{2}+\mathrm{H}_{2}$

The basically catalytic mechanism of the steam reforming of tar is the 


\section{Steam reforming of biomass tar}

\subsection{Tar formation and properties}

Tars are generally formed in the pyrolysis step due to the decomposition of lignocellulosic biomass. The main components in this step are mostly oxygenated hydrocarbons. With the increase in the reaction temperature, the oxygenated hydrocarbons can be converted to light hydrocarbons, aromatics and olefins, which are then converted to higher hydrocarbons and larger polycyclic aromatic hydrocarbons. The schematic of tar formation as a function of temperature is shown in Fig. 4. It can be seen that the organic compounds become more stable with the increase in temperature. Therefore, temperature is the key factor for tar distribution. 
Fig. 4 Tar maturation scheme (Modified from Elliott 1988) [44].

Tar can be classified by various ways. For instances, based on its appearance, tar can be divided as primary, secondary and tertiary tars as shown in Table 2. Based on molecular weight, tar can be divided into 5 classes as shown in Table 3 . Tar problem is not mainly concerned with the tar quantity, but with the properties and the compositions of $\operatorname{tar}[33]$.

Table 2. Tar classification based on its appearance $[45,98,119]$.

Table 3. Tar classification based on molecular weight of tar compounds [33,98].

The typical composition of biomass tar is shown in Fig. 5. However, the amount and composition of tar produced in biomass gasification depends on many factors such as type of biomass feedstock, gasifier type and gasifying agent, and operating conditions such as temperature and pressure. Yu et al. [46] studied tar formation characteristics for the gasification of major biomass components (i.e., cellulose, hemicellulose and lignin) and revealed that lignin has higher tar yields and results in the formation of more stable components in tar than others but the tar composition shifts toward higher-molecular-weight substances such as PAHs at higher temperature. Meng et al. [31] reported that with the increasing of temperature the total produced tar decreases. Moreover, the temperature affects not only tar formation yield but also the tar 
properties. Han and Kim [11] reported that with the increase in the temperature more class 1 and 2 tars are decomposed but more class 3 and 5 tars are formed. For the gasifying agent, the additions of steam and oxygen can greatly reduce the tar yield [47].

Fig. 5. Typical composition of biomass tars $[48,120]$.

\subsection{Catalytic steam reforming of tar}

As stated above, among tar removal techniques, catalytic steam reforming is the most attractive technique since the presence of catalyst can remove tar more effectively and simultaneously convert tar into useful gas $\left(\mathrm{H}_{2}, \mathrm{CH}_{4}\right.$, and $\left.\mathrm{CO}\right)$ at lower temperature than non-catalytic tar conversion. During catalytic steam reforming, many reactions take place simultaneously and the product distribution is a result of the competition among them. Those reactions can be summarized as follows [1,33]:

Thermal cracking: $\quad p \mathrm{C}_{n} \mathrm{H}_{x}($ tar $) \rightarrow q \mathrm{C}_{m} \mathrm{H}_{y}$ (smaller tar) $+r \mathrm{H}_{2}$

Steam reforming: $\quad \mathrm{C}_{n} \mathrm{H}_{x}(\operatorname{tar})+n \mathrm{H}_{2} \mathrm{O} \rightarrow(n+x / 2) \mathrm{H}_{2}+n \mathrm{CO}$

Dry reforming: $\quad \mathrm{C}_{n} \mathrm{H}_{x}(\mathrm{tar})+n \mathrm{CO}_{2} \rightarrow(x / 2) \mathrm{H}_{2}+2 n \mathrm{CO}$

Carbon formation: $\quad \mathrm{C}_{n} \mathrm{H}_{x}(\operatorname{tar}) \rightarrow n \mathrm{C}+(x / 2) \mathrm{H}_{2}$

and reactions (1)-(13).

It is expected that all tar can be converted by steam into simpler and lighter molecules like $\mathrm{H}_{2}$ and $\mathrm{CO}$. In case of excess steam, the produced $\mathrm{CO}$ could react further with steam, producing more $\mathrm{H}_{2}$. Many researchers studied the tar removal by catalytic steam reforming [38, 49-54]. For instances, Kim et al. [50] investigated the catalytic conversion of tar under inert and steam reforming conditions and found that catalytic 
steam reforming of tar exhibited lower tar yield and less coke deposition on catalyst surface than the inert condition. Miyazawa et al. [51] investigated the catalytic performances of various supported $\mathrm{Ni}$ catalysts for the steam reforming of tar derived from cedar and found that no tar was observed when using $\mathrm{Ni} / \mathrm{Al}_{2} \mathrm{O}_{3}, \mathrm{Ni} / \mathrm{ZrO}_{2}$ or $\mathrm{Ni} / \mathrm{TiO}_{2}$ as the catalyst at a reaction temperature of $650{ }^{\circ} \mathrm{C}$. Li et al. [52] also reported that the steam reforming of biomass tar over $\mathrm{BaAl}_{12} \mathrm{O}_{19}$-supported Co catalyst effectively removed almost all tar at relatively low temperature of $550{ }^{\circ} \mathrm{C}$.

\subsection{Mechanism of catalytic steam reforming of tar}

Due to the complexity of real tar, most researchers used the model tar compounds such as benzene, toluene, or naphthalene to study the catalytic mechanism [55-60]. For instances, Bampenrat et al. [55] studied steam reforming of naphthalene over nickel supported on $\mathrm{Ce}_{0.75} \mathrm{Zr}_{0.25-\mathrm{x}} \mathrm{Mn}_{\mathrm{x}} \mathrm{O}_{2}$ mixed oxide catalysts and found that the complete naphthalene conversion can be remained for at least $6 \mathrm{~h}$ on stream. Ferella et al. [57] also studied the steam reforming of naphthalene as a model tar over $\mathrm{ZrO}_{2^{-}}$and $\mathrm{Al}_{2} \mathrm{O}_{3}$-supported catalysts and found that $\mathrm{Al}_{2} \mathrm{O}_{3}$-supported active metal catalysts were more active than zirconia ones, achieving 90-100\% of naphthalene conversion even at $500{ }^{\circ} \mathrm{C}$. Zhao et al. [58] used toluene as model tar compound to study the catalytic performance of $\mathrm{Ni} /$ cordierite catalyst and found that the conversion of toluene increased with temperature, reaching $94.1 \%$ at $900{ }^{\circ} \mathrm{C}$. Park et al. [59] investigated steam reforming of benzene over various nickel supported metal oxide catalysts and reported that 15 wt. $\% \mathrm{Ni} / \mathrm{CeO}_{2}(75 \%)-\mathrm{ZrO}_{2}(25 \%)$ showed the highest catalytic performance with a $87 \%$ of benzene conversion.

Jess [61] studied the mechanisms and kinetics of thermal conversions of aromatic 
hydrocarbons derived from solid fuels, using naphthalene, toluene and benzene as the model compounds and proposed the simplified reaction scheme in the presence of hydrogen and steam as shown in Fig. 6. He concluded that benzene should be the key component of thermal decomposition of aromatic hydrocarbons. Carbonaceous residue (soot) formed is principally from the large hydrocarbon molecules such as naphthalene. He also indicated that the soot and organic cracking products can be completely converted to $\mathrm{CO}$ and $\mathrm{H}_{2}$ in the presence of steam at a high temperature of $1400{ }^{\circ} \mathrm{C}$. Rama et al. [62] studied the catalytic activity and stability of oxidation pretreated Ni-containing alloy tube catalysts in the steam reforming of model compounds of tetradecane, toluene and naphthalene, and found that during thermal cracking, straight-chained hydrocarbons easily convert to shorter and simpler hydrocarbons whereas aromatic hydrocarbons dominantly change to benzene which is easy to form carbon. As a result, the higher amount of carbon was formed in the case of naphthalene when compared to toluene due to its 2-ringed structure. The coke formation during cracking is the main factor for the catalyst deactivation since it could encapsulate the active sites of the catalyst. Chen et al. [63] also reported that the coke deposited on the catalyst is mainly from polycyclic aromatic hydrocarbons (PAHs), which could undergo series of reactions of dehydrogenation, cyclization, and condensation, and result in the formation of larger polyaromatic molecules and coke. However, the coke formation during cracking can be avoided by increasing the temperature.

Fig. 6. Simplified reaction scheme of thermal conversion of aromatic hydrocarbons in the presence of hydrogen and steam (Modified from Jess 1996) [61]. 
In our previous studies[38,39, 64-66], various catalysts were developed for the steam reforming of tar in the biomass gasification process. In order to describe about its mechanism, all tar components are considered as one group (tar mixture) and the proposed mechanism of catalytic steam reforming of biomass derived tar is shown in Fig. 7. The volatiles produced in the pyrolysis step are passed over the catalyst layer. Tar molecules are broken down to lighter molecules and reformed to useful gaseous fuels $\left(\mathrm{CO}\right.$ and $\left.\mathrm{H}_{2}\right)$ on the active sites of catalysts via several simultaneous reactions (thermal cracking, steam reforming, dry reforming, carbon formation, water-gas shift, etc.). In the same time, tar molecules are also decomposed and formed free radicals which can further generate coking on the catalyst surface via polymerization reactions.

Fig. 7. Mechanism of catalytic steam reforming of biomass derived tar supposed in our study $\left(\mathrm{M}_{\mathrm{x}} \mathrm{O}_{\mathrm{y}}\right.$ represents metal oxide catalyst) [121].

\section{The prospects of catalytic reforming of tar}

There are several types of catalysts that have potential for catalytic reforming of tar. The catalyst may be selected according the following criteria based on its properties [67]:

- Effectiveness for tar reforming

- Activity in the reforming of heavy hydrocarbon and aromatic compounds.

- Ability to provide a suitable syngas ratio for special purpose.

- Resistance to deactivation due to coking, sintering and impurity fouling.

- Stability and reusability.

- Mechanical strength. 
- Cost and availability.

\subsection{Nickel-based catalysts}

Ni-based catalysts are used extensively for biomass tar conversion because of their high tar destruction activity, along with the added activity for methane reforming and water-gas shift $[51,59,68-70]$. Some studies also showed that Ni-based catalysts had the ability for the reversing ammonia reaction, thus it is also possible to reduce $\mathrm{NO}_{\mathrm{x}}$ emission during biomass gasification and tar reforming [43].

$\mathrm{Ni}$ is generally supported on various materials. To date, $\mathrm{Ni} / \mathrm{Al}_{2} \mathrm{O}_{3}, \mathrm{Ni} /$ olivine, $\mathrm{Ni} / \mathrm{ZrO}_{2}, \mathrm{Ni} / \mathrm{TiO}_{2}, \mathrm{Ni} / \mathrm{CeO}_{2}$, and $\mathrm{Ni} / \mathrm{MgO}$ have been extensively studied by many researchers. However, the main limitation of nickel-based catalysts is the rapid deactivation, caused by carbon formation on the catalyst surface. Świerczyński et al. [10] studied the activity of Ni/olivine catalyst for tar reforming using toluene as a model tar compound, and its resistance to deactivation by carbon deposition in a fixed bed reactor. They found that Ni/olivine catalyst exhibited higher activity, higher selectivity to $\mathrm{H}_{2}$ and $\mathrm{CO}$, and lower carbon deposition when compared to olivine alone. The reason of this stability can be explained by the strong metal-support interactions (Ni-/Fe/MgO/olivine system), which provide resistance against carbon formation.

Recently, some researchers tried to add the second metal additive to improve the stability as well as activity of supported nickel catalysts. Zhang et al. [71] studied the steam reforming of tar over $\mathrm{Ni} /$ olivine catalysts doped with $\mathrm{CeO}_{2}$, and found that the doping of $\mathrm{CeO}_{2}$ had particular effectiveness in terms of both catalytic activity and coking resistance. The promoting effect of cerium oxide on the nickel catalyst is probably through a redox mechanism. The lower valence state of cerium might adsorb 


\subsection{Non-nickel transition metal catalysts}

Non-nickel metal catalysts such as $\mathrm{Rh}, \mathrm{Ru}, \mathrm{Pd}, \mathrm{Pt}, \mathrm{Co}, \mathrm{Fe}$, etc. have been developed for the steam reforming of biomass tar. Several literatures reported that noble metal catalysts such as $\mathrm{Ru}, \mathrm{Rh}$, and Pt have very high catalytic activity with high sulfur resistance and long term stability in the steam reforming of tar [77,78]. Tomoshige et al. [79] studied the catalytic activity of noble metal catalysts supported on $\mathrm{CeO}_{2} / \mathrm{SiO}_{2}$ for the steam reforming of tar and compared with Ni-based catalysts. It is found that $\mathrm{Rh} /$ $\mathrm{CeO}_{2} / \mathrm{SiO}_{2}$ catalyst had better performance than the commercial Ni catalysts. Among the noble metals, Rh was found to be significantly more active than others with a selectivity order of $\mathrm{Rh}>\mathrm{Pt}>\mathrm{Pd}>\mathrm{Ru}=\mathrm{Ni}$. Recently, $\mathrm{Ru}$ was supported on $12 \mathrm{SrO}-7 \mathrm{Al}_{2} \mathrm{O}_{3}$, which can incorporate active oxygen ions into the nanocage, and applied for the steam 
reforming of dodecane and toluene. As a result, $\mathrm{Ru} / 12 \mathrm{SrO}-7 \mathrm{Al}_{2} \mathrm{O}_{3}$ showed superior catalytic performance with a high coking resistance $[80,81]$. To reduce cost and improve reforming economics by using these noble metals, low loadings (for instance, $<1 \mathrm{wt} \%$ ) of them on some special materials were also found to have high catalytic performances at low temperatures, which can be considered as potential industrial catalysts for the tar steam reforming[82,83]. Even so, noble metals are still expensive when comparing with other catalysts.

Besides noble catalysts, other metal catalysts like $\mathrm{Co}, \mathrm{Fe}, \mathrm{Zn}$, and $\mathrm{Cu}$ have also been investigated in the steam reforming of tar, and some of them showed higher catalytic activity than $\mathrm{Ni}$ catalyst $[12,52,84,85]$. For instances, Furusawa and Tsutsumi [12] reported that Co loaded $\mathrm{MgO}$ showed better tar reforming performance and higher catalytic activity than $\mathrm{Ni}$ loaded $\mathrm{MgO}$. Li et al. [52] reported that $\mathrm{Co}$ supported on $\mathrm{BaAl}_{12} \mathrm{O}_{19}$ (BA) showed high activity and high reusability in the steam reforming of tar due to the high dispersion of Co particles on BA. To improve the performance in steam reforming of tar, bimetallic or trimetallic catalysts were also investigated [34,86,87]. Noichi et al. [34] studied the effects of addition of copper species to the iron-based mixed metal oxides such as iron-alumina (Fe- $\mathrm{Al})$ and iron-zirconia (Fe-Zr) catalysts on the catalytic activity in steam reforming of naphthalene as model biomass tar. They found that the addition of $\mathrm{Cu}$ increased the activity and stability of the Fe-Al catalyst because the well dispersed copper in the compound oxide facilitated the reduction of iron oxide to metallic iron and prevent the catalytic deactivation. Wang et al. [87] modified the $\mathrm{Co} / \mathrm{Al}_{2} \mathrm{O}_{3}$ with $\mathrm{Fe}$ and investigated the performance of $\mathrm{Co}-\mathrm{Fe} / \mathrm{Al}_{2} \mathrm{O}_{3}$ catalysts in the steam reforming of tar and found that the addition of $\mathrm{Fe}$ to $\mathrm{Co} / \mathrm{Al}_{2} \mathrm{O}_{3}$ at the optimum amount enhanced the catalytic 
performance in terms of the catalytic activity and the suppression of coke deposition.

\subsection{Alkali catalysts}

Alkali metals are the metal belonging to group 1A of the periodic table such as lithium $(\mathrm{Li})$, sodium $(\mathrm{Na})$, potassium $(\mathrm{K})$. Many studies proved that alkali metal catalysts are very effective in steam reforming of tar and can improve the quality of gaseous product [88-90]. However, the major disadvantage of these catalysts is their evaporation during the reaction and difficult recovery. Kuchonthara et al. [89] studied the catalytic activity of $\mathrm{K}_{2} \mathrm{CO}_{3}$ on the steam gasification of lignin and found that $\mathrm{K}_{2} \mathrm{CO}_{3}$ had a good catalytic activity for tar decomposition during pyrolysis and steam gasification. Particularly, almost all components in biomass were completely converted at $800{ }^{\circ} \mathrm{C}$. On the other hand, the alkali species contained in biomass always plays catalytic role in the thermal conversion process and the released alkali species may also act as catalyst for the steam reforming of tar in the gasification process. Hognon et al. [90] studied the influence of inorganic elements in the biomass itself on the steam gasification of biomass, and confirmed that the difference of the reactivity of various biomass depends on the inorganic elements in them. The high reactivity was observed for the biomass samples contained high amount of potassium, which is known to act as catalyst in char gasification as well as tar reforming. Some researchers studied co-gasification of coal and biomass [91-93], and found that the total gas yield in co-gasification was higher than those expected based on the results of gasification of coal or biomass alone. This is due to the synergy effects which are related to the catalytic activity of some of ash components, e.g. alkali and alkali earth metals, in the biomass. Moreover, the use of ashes as catalysts gives some advantages such as 
avoiding the problem of the handling of ash wastes [94].

\subsection{Natural catalysts}

Natural minerals such as dolomite, olivine, and shells can be used as catalysts directly or with some pretreatment such as calcination. These natural catalysts are inexpensive and abundant and show considerable activity for the reforming of tar $[25$, 39, 42, 95-105]. Hu et al. [99] found that both olivine and dolomite were active for the steam reforming of tar into $\mathrm{H}_{2}$-rich gas. Furthermore, the catalytic activity of these catalysts can be improved by calcining them at $900{ }^{\circ} \mathrm{C}$ for $4 \mathrm{~h}$. Among all the catalysts tested, the calcined dolomite was the most effective catalyst for increasing $\mathrm{H}_{2}$ content in the gaseous product. However, dolomite became very friable after calcination, making them not suitable to be used in the fluidized bed gasifier. Roche et al. [100] applied dolomite for air-steam gasification of sewage sludge, and found that $\mathrm{H}_{2}$ content increased while tar content decreased, reaching a tar removal efficiency up to $71 \%$. Besides dolomite, some research groups investigated olivine as a tar reforming catalyst [92,101-104]. Constantinou et al. [96] reported that calcined olivine had good performance for tar reduction and its activity was comparable to the calcined dolomite. Moreover, some researchers mentioned that the catalytic activity of olivine can be further improved by the addition of some metals. Michel et al. [103] compared the catalytic activity of olivine with olivine supported nickel for the steam reforming of tar, and found that the Ni/olivine had much higher ability for the tar reforming than olivine alone. Virginie et al. [104] reported that toluene conversion and hydrogen production when using Fe/olivine catalyst were approximately 3 times higher than the case using olivine alone. Yang et al. [105] attempted to improve the catalytic activity of olivine by 
modification of olivine with calcium aluminate cement and found that porosity of catalysts increased above $30 \%$ and the obtained catalyst exhibited higher catalytic activity and stability due to the pore structure and the well dispersion of $\mathrm{Ni}$ particles on the catalyst. Moreover, the advantage of olivine catalyst over dolomite catalyst is its high attrition resistance, which is more suitable to be used in fluidized bed gasifier.

\subsection{Zeolite catalysts}

Zeolites are crystalline silicates and aluminosilicates linked through oxygen atoms, producing a three-dimensional network containing channels and cavities of molecular dimensions [106]. Zeolites have been widely used in heterogeneous catalysis because of their well-defined pore structure and extremely high surface area and surface acidity. The modification of zeolites with dispersed metals can obtain catalysts for hydrogenation and ring-breaking of aromatic hydrocarbons. Such catalysts showed relatively high tolerance for sulfur compounds in the clean-up of gasification effluents [107]. In the case of tar reduction, various kinds of zeolites, especially the commercial catalysts, were tested by some researchers [65,108-112]. Dou et al. [111] studied the catalytic cracking of tar component over five kinds of catalysts, i.e., Y-zeolite, NiMo catalyst, silica, alumina and lime, and found that Y-zeolite and NiMo catalysts were the most effective catalysts, which removed almost $100 \%$ tar at $550{ }^{\circ} \mathrm{C}$ but no deactivation was observed over $10 \mathrm{~h}$ test. Some researchers revealed that the catalytic activity of zeolite depends on the pore size and acidity. Buchireddy et al. [112] studied the catalytic activity of zeolites with varying pore size and acidity and nickel supported zeolites for tar reforming. Their results indicated that Y-zeolite had better catalytic activity due to its larger pore size when compared with ZSM-5. Moreover, the catalytic activity of 
zeolites increased with the increase in the acidity. It is found that the impregnation of nickel on zeolites improved the activity significantly. The advantages of zeolites are related to their acidity, better thermal/hydrothermal stability, better resistance to nitrogen and sulfur compounds, and easy to be regenerated. However, the main disadvantages of these catalysts are the rapid deactivation resulted from coke formation [38].

\subsection{Carbon-supported catalysts}

Activated carbons (AC) and char derived from biomass and coal have been widely used as catalyst supports for the conversion of hydrocarbons and tar cracking due to their highly porous textural structures [6,107]. Their catalytic activities for tar elimination are related to the pore size, the surface area, and the ash or mineral content in them. The attractiveness of char as a catalyst is its low cost and its natural production [38]. The performance of char and char-supported catalysts for tar conversion can be found in several literatures [36,115-118]. El-Rub et al. [36] studied the potential of using biomass char as a catalyst for tar reduction and compared with other known catalysts, i.e., calcined dolomite, olivine, spent fluid catalytic cracking (FCC) catalyst, biomass ash and commercial nickel catalyst. The results indicated that biomass chars had the highest naphthalene conversion with an order of nickel > commercial biomass char $>$ biomass char $>$ biomass ash $>$ FCC $>$ dolomite $>$ olivine $>$ silica sand. Min et al. [117] also studied the catalytic activity of char and char-supported catalysts in steam reforming of tar. Their results showed that the char-supported iron/nickel catalysts exhibited much higher activity than the char itself. The similar result was also found by Zhang et al. [116]. They investigated the effectiveness of tar reforming using biomass 
char, iron supported biomass char and iron supported brown coal char. The results indicated that biomass char supported iron catalyst had much higher activity than coal char supported iron catalysts. They concluded that the activity should be related to the structure in char support. Bhandari et al. [118] investigated the catalytic performances of three synthesized catalysts including biochar, activated carbon and acidic surface activated carbon, and found that all three catalysts were effective in tar removal with removal efficiencies of $69-92 \%$. Especially, activated carbon catalysts had higher toluene removal efficiency because of their higher surface area, larger pore diameter and larger pore volume compared to biochar catalysts.

\section{Conclusions and remarks}

As reviewed above, the developed catalysts with advantages and disadvantages that can be summarized as the following. Nickel-based catalysts have been used extensively for the steam reforming of tar due to their high activity, but the main disadvantage of these catalysts is the rapid deactivation by carbon formation on the surface of catalyst. Although noble metal based catalysts have high catalytic activity, long-term stability and high carbon deposition resistance, they are expensive. Beside noble metal based catalysts, other transition metal catalysts such as $\mathrm{Fe}, \mathrm{Co}$ and $\mathrm{Cu}$ also exhibit a good performance in the steam reforming of tar. However, they are deactivated easily by carbon deposition in the case of high heavy-tar content in the produced tar. Alkali metal catalysts also have high catalytic activity in the steam reforming of tar. Especially, alkali species contained in biomass can also act as a catalyst for tar reforming, making the utilization of biomass ash as the catalyst is becoming interesting since it can reduce the problem of ash-handling during biomass gasification. Natural 
catalysts have also been widely applied for the steam reforming of tar due to its inexpensive, abundant and disposable. Sometimes their catalytic activities are lower than those man-made ones, but they are much cheaper than the latter. Another main problem of these catalysts is their low mechanical strength, making them not suitable to be used in fluidized bed reactor. Zeolite can be a good catalyst support in the steam reforming of tar due to its high thermal/hydrothermal stability, high resistance to sulfur compounds, and easy to be regenerated. Besides zeolite, biomass char have also been used as a catalyst or catalyst support in the steam reforming of tar. The advantages of biomass char are its low cost and its natural production inside the biomass gasifier. Moreover, the minerals contained in biomass can also enhance the catalytic activity of biomass char.

On the other hand, since the compositions of biomass-derived tar are very complex, during catalytic tar reforming process, a matrix of complex reactions among different compositions and gases will occur. The relationship between different reactions is difficult to be known so that it is almost impossible to predict the mechanism of the catalytic process exactly. Various man-made catalysts such as metal supported catalysts have been successfully developed for the decomposition of model tars such as benzene, toluene, phenol and naphthalene. However, most of them are still unsuitable for a real tar reforming. Moreover, for a practical biomass gasification process, in order to reform the complex tars, using low-cost and disposable catalysts still attracts special attention.

In the future work, the following points should be considered in order to realize complete conversion of tar into syngas:

(1) Steam reforming of heavy tar To date, the mechanism on the steam reforming of heavy tar on the catalyst is still not clear. In general, coking on the catalyst 
(2) Novel catalyst development Coking on the catalyst surface is almost the main reason for any catalyst deactivation in the steam reforming of tar. Therefore, structure and composition design of catalyst based on the coking mechanism analysis is required for novel catalyst development. Structure design could help different components with different molecular structures in the tar to find a suitable active site for its complete conversion. Due to the complex of the tar, one composition in a catalyst could not be suitable for the conversion of all molecules in the tar, and thus, it is necessary to develop composite catalysts with several compositions for the reforming of real tar. On the other hand, besides coking, some impurities such as $\mathrm{S}, \mathrm{P}, \mathrm{N}, \mathrm{Si}$, and other minerals in the real tar also have negative effects on the catalyst deactivation. Basic researches on these is still not enough. More experiments on the effect of these impurities should be considered. Furthermore, in order to decrease the energy consumption in the reforming of tar, it is necessary to develop catalysts with high activity at lower temperature. If the developed catalysts can work well at lower temperatures, waste heat with a temperature of $400-600{ }^{\circ} \mathrm{C}$ in the factory can be effectively used. For practical application, the catalyst strength should also be considered since many catalysts are fragile 
and cannot be used in fluidized bed reactors.

(3) Scale-up issues To date, catalyst development is generally performed in the laboratory scale. Not so many data can be found from larger scale or pilot experiments by using these catalysts. In the lab scale, these catalysts may show good catalytic properties for the reforming of model tar or even for real tar. However, in larger scale reactors, the factors on the activity of catalyst become very complex. Some important factors such as gas flow rate, temperature and pressure variations, catalyst broken, the impurities such as $\mathrm{HCl}, \mathrm{HCN}, \mathrm{NO}_{\mathrm{x}}, \mathrm{SO}_{\mathrm{x}}$ and fly ash in the gas line must be considered. Otherwise, any good catalysts obtained in the laboratory cannot be used in a practical process.

(4) Catalyst regeneration technology In a practical process, a chemical looping system design for continuous tar removal with simultaneous catalyst regeneration is always considered. In general, the catalyst even with high activity in a small scale experiment could be deactivated in a practical system due to the complexity of the tar compositions and operation conditions. Although some natural low-cost catalysts can be discarded after deactivated, how to regenerate the catalyst rapidly is still an important issue for the catalyst development, especially for those man-made catalysts with relatively high manufacture cost.

If all of the above issues can be resolved well, tar problem in biomass gasification will be well solved and effective utilization of the by-produced tar could be really realized. This will promote application of biomass energy in our daily life. 


\section{Acknowledgements}

This work is supported by Japan Science and Technology Agency (JST), Strategic International Collaborative Research Program (SICORP), Japan and Aomori City Government, Japan, and the International Joint Research Project of Shanxi Province (No.2015081051and 2015081052), China. M. Kaewpanha gratefully acknowledges the scholarship from the Ministry of Education, Culture, Sports, Science and Technology (MEXT) of Japan, and research fund for $\mathrm{PhD}$ course student from Hirosaki University.

\section{References}

[1] Alauddin ZABZ, Lahijani P. Gasification of lignocellulosic biomass in fluidized beds for renewable energy development: A review. Renew Sustain Energy Rev 2010;14:2852-62.

[2] Bhavanam A, Sastry RC. Biomass gasification processes in downdraft fixed bed reactors: A review. Int J Chem Eng Appl 2011;2:425-33.

[3] Damartzis T, Zabaniotou A. Thermochemical conversion of biomass to second generation biofuels through integrated process design-a review. Renew Sustain Energy Rev 2011; 15:366-78.

[4] Kirkels AF, Verbong GPJ. Biomass gasification: still promising? A 30-year global overview. Renew Sustain Energy Rev 2011; 15:471-81. 
[5] Göransson K, Söderlind U, He J, Zhang W. Review of syngas production via biomass DFBGs. Renew Sustain Energy Rev 2011; 15:472-92.

[6] Shen Y. Chars as carbonaceous adsorbents/catalysts for tar elimination during biomass pyrolysis or gasification. Renew Sustain Energy Rev 2011; 43:281-95.

[7] Kumar A, Jones DD. Thermochemical biomass gasification: a review of the current status of the technology. Energies 2009;2:556-81.

[8] IEA, World Energy Outlook 2011, International Energy Agency: Paris, France, 2011.

[9] Basu P, Biomass gasification and pyrolysis: practical design and theory, Published by Elsevier Inc., 2010.

[10] Świerczyński D, Libs S, Courson C, Kiennemann A. Steam reforming of tar from a biomass gasification process over $\mathrm{Ni} /$ olivine catalyst using toluene as a model compound. Appl Catal B: Environ 2007;74:211-22.

[11] Han J, Kim H. The reduction and control technology of tar during biomass gasification/pyrolysis: An overview. Renew Sustain Energy Rev 2008;12:397-416.

[12] Furusawa $\mathrm{T}$, Tsutsumi A. Comparison of $\mathrm{Co} / \mathrm{MgO}$ and $\mathrm{Ni} / \mathrm{MgO}$ catalysts for the steam reforming of naphthalene as a model compound of tar derived from biomass gasification. Appl Catal A: Gen 2005;278:207-12.

[13] Ruiz JA, Juárez MC, Morales MP, Munoz P, Mendívil MA. Biomass gasification for electricity generation: Review of current technology barriers. Renew Sustain Energy Rev 2013;18:174-83.

[14] Shen Y, Zhao P, Shao Q, Ma D, Takahashi F, Yoshikawa K. In-situ catalytic conversion of tar using rice husk char-supported nickel-iron catalysts for biomass 
[15] Udomsirichakorn J, Salam PA. Review of hydrogen-enriched gas production from steam gasification of biomass: The prospect of $\mathrm{CaO}$-based chemical looping gasification. Renew Sustain Energy Rev 2014;30:565-79.

[16] Bocci E, Sisinni M, Moneti M, Vecchione L, Di Carlo A, Villarini M. State of art of small scale biomass gasification power systems: a review of the different typologies. Energy Procedia 2014;45:247-56.

[17] Tröger N, Richter D, Stahl R. Effect of feedstock composition on product yields and energy recovery rates of fast pyrolysis products from different straw types. J Analy Appl Pyrolysis 2013;100:158-65.

[18] Hanaoka T, Hiasa S, Edashige Y. Syngas production by $\mathrm{CO}_{2} / \mathrm{O}_{2}$ gasification of aquatic biomass. Fuel Process Technol 2013;116:9-15.

[19] Kaewpanha M, Guan G, Hao X, Wang Z, Kasai Y, Kusakabe K, Abudula A. Steam co-gasification of brown seaweed and land-based biomass. Fuel Process Technol 2014; 120: 106-112.

[20] Yang KC, Wu KT, Hsieh MH, Hsu HT, Chen CS, Chen HW. Co-gasification of woody biomass and microalgae in a fluidized bed. J Taiwan Inst Chem Eng 2013;44:1027-33.

[21] Asadullah M, Miyazawa T, Ito S, Kunimori K, Yamada M, Tomishige K. Gasification of different biomasses in a dual-bed gasifier system combined with novel catalysts with high energy efficiency. Appl Catal A: Gen 2004;267:95-102.

[22] Lapuerta M, Hernández JJ, Pazo A, López J. Gasification and co-gasification of biomass wastes: Effect of the biomass origin and the gasifier operating conditions. Fuel Process Technol 2008;89:828-37. 
[23] Taba LE, Irfan MF, Daud WAMW, Chakrabarti MH. The effect of temperature on various parameters in coal, biomass and CO-gasification: A review. Renew Sustain Energy Rev 2012;16:5584-96.

[24] Yan F, Luo S, Hu Z, Xiao B, Cheng G. Hydrogen-rich gas production by steam gasification of char from biomass fast pyrolysis in a fixed-bed reactor: Influence of temperature and steam on hydrogen yield and syngas composition. Bioresour Technol 2010;101:5633-7.

[25] Min Z, Asadullah M, Yimsiri P, Zhang S, Wu H, Li CZ. Catalytic reforming of tar during gasification. Part I. Steam reforming of biomass tar using ilmenite as a catalyst. Fuel 2011;90:1847-54

[26] Erkiaga A, Lopez G, Amutio M, Bilbao J, Olazar M. Influence of operating conditions on the steam gasification of biomass in a conical spouted bed reactor. Chem Eng J 2014;237:259-67.

[27] Berrueco C, Montané D, Güell BM, Alamo GD. Effect of temperature and dolomite on tar formation during gasification of torrefied biomass in a pressurized fluidized bed. Energy 2014;66:849-59.

[28] Parthasarathy P, Narayanan KS. Hydrogen production from steam gasification of biomass: Influence of process parameters on hydrogen yield-A review. Renew Energy 2014;66:570-9.

[29] Xiao X, Le DD. Catalytic steam gasification of biomass in fluidized bed at low temperature: Conversion from livestock manure compost to hydrogen-rich syngas. Biomass Bioenergy 2010;34:1505-12.

[30] Luo S, Xiao B, Hu Z, Liu S, Guo X, He M. Hydrogen-rich gas from catalytic steam gasification of biomass in a fixed bed reactor: Influence of temperature and 
steam on gasification performance. Int J Hydrogen Energy 2009;34:2191-4.

[31] Meng X, Jong W, Fu N, Verkooijen AHM. Biomass gasification in a $100 \mathrm{kWth}$ steam-oxygen blown circulating fluidized bed gasifier: Effects of operational conditions on product gas distribution and tar formation. Biomass Bioenergy 2011;35:2910-24.

[32] Lv PM, Xiong ZH, Chang J, Wu CZ, Chen Y, Zhu JX. An experimental study on biomass air-steam gasification in a fluidized bed. Bioresour Technol 2004;95:95-101.

[33] Li C, Suzuki K. Tar property, analysis, reforming mechanism and model for biomass gasification-An overview. Renew Sustain Energy Rev 2009;13:594-604.

[34] Noichi H, Uddin A, Sasaoka E. Steam reforming of naphthalene as model biomass tar over iron-aluminum and iron-zirconium oxide catalyst catalysts. Fuel Process Technol 2010;91:1609-16.

[35] Sutton D, Kelleher B, Ross JRH. Review of literature on catalysts for biomass gasification. Fuel Process Technol 2011;73:155-73.

[36] El-Rub ZA, Bramer EA, Brem G. Review of catalysts for tar elimination in biomass gasification processes. Ind Eng Chem Res 2004;43:6911-9.

[37] Nilsson S, Gómez-Barea A, Fuentes-Cano D, Ollero P. Gasification of biomass and waste in a staged fluidized bed gasifier: Modeling and comparison with one-stage units. Fuel 2012;97:730-40.

[38] Huang BS, Chen HY, Kuo JH, Chang CH, Wey MY. Catalytic upgrading of syngas from fluidized bed air gasification of sawdust. Bioresour Technol 2012;110:670-5. 
[39] Guan G, Kaewpanha M, Hao X, Zhu A, Kasai Y, Kakuta S, et al. Steam reforming of tar derived from lignin over pompom-like potassium-promoted iron-based catalysts formed on calcined scallop shell. Bioresource Technol 2013;139:280-4.

[40] Li C, Hirabayashi D, Suzuki K. Steam reforming of biomass tar producing $\mathrm{H}_{2}$-rich gases over $\mathrm{Ni} / \mathrm{MgO}_{\mathrm{x}} / \mathrm{CaO}_{1-\mathrm{x}}$ catalyst. Bioresour Technol 2010;101:S97-100.

[41] Cao JP, Shi P, Zhao XY, Wei XY, Takarada T. Catalytic reforming of volatiles and nitrogen compounds from sewage sludge pyrolysis to clean hydrogen and synthetic gas over a nickel catalyst. Fuel Process Technol 2014;123:34-40.

[42] Guan G, Chen G, Kasai Y, Lim EWC, Hao X, Kaewpanha M, et al. Catalytic steam reforming of biomass tar over iron- or nickel-based catalyst supported on calcined scallop shell. Appl Catal B: Environ 2012;115-116:159-68.

[43] Dayton D, A review of the literature on catalytic biomass tar destruction, NREL, Golden, Colorado, USA, (NREL/TP-510-32815), 2002.

[44] Elliott DC. Relation of reaction time and temperature to chemical composition of pyrolysis oils. In: Soltes EJ, Milne, editors. ACS symposium series 376, pyrolysis oils from biomass, 1988.

[45] Palma CF. Modelling of tar formation and evolution for biomass gasification: A review. Appl Energy 2012;111:129-41.

[46] Yu H, Zhang Z, Li Z, Chen D. Characteristics of tar formation during cellulose, hemicellulose and lignin gasification. Fuel 2014;118:250-6.

[47] Qin YH, Feng J, Li WY. Formation of tar and its characterization during air-steam gasification of sawdust in a fluidized bed reactor. Fuel 2010;89:1344-7.

[48] Shen S, Yoshikawa K. Recent progresses in catalytic tar elimination during biomass gasification or pyrolysis-A review. Renew Sustain Energy Rev 
$2013 ; 21: 371-92$

[49] Wang L, Li D, Koike M, Watanabe H, Xu Y, Nakagawa Y, et al. Catalytic performance and characterization of Ni-Co catalysts for the steam reforming of biomass tar to synthesis gas. Fuel 2013;112:654-61.

[50] Kim YK, Park JI, Jung D, Miyawaki J, Yoon SH, Mochida I. Low-temperature catalytic conversion of lignite: 3 . Tar reforming using the supported potassium carbonate. J Ind Eng Chem 2014;20:9-12.

[51] Miyazawa T, Kimura T, Nishikawa J, Kado S, Kunimori K, Tomishige K. Catalytic performance of supported $\mathrm{Ni}$ catalysts in partial oxidation and steam reforming of tar derived from the pyrolysis of wood biomass. Catal Today 2006;115:254-62.

[52] Li D, Ishikawa C, Koike M, Wang L, Nakagawa Y, Tomishige K. Production of renewable hydrogen by steam reforming of tar from biomass pyrolysis over supported Co catalysts. Int J Hydrogen Energy 2013;38:3572-81.

[53] Kimura T, Miyazawa T, Nishikawa J, Kado S, Okumura K, Miyao T, et al. Development of $\mathrm{Ni}$ catalysts for tar removal by steam gasification of biomass. Appl Catal B: Environ 2006;68:160-70.

[54] Basile F, Albertazzi S, Barbera D, Benito P, Einvall J, Brandin J, et al. Steam reforming of hot gas from gasified wood types and miscanthus biomass. Biomass Bioenergy 2011;35:S116-22.

[55] Bampenrat A, Meeyoo V, Kitiyanan B, Rangsunvigit P, Rirksomboon T. Naphthalene steam reforming over $\mathrm{Mn}$-doped $\mathrm{CeO}_{2}-\mathrm{ZrO}_{2}$ supported nickel catalysts. Appl Catal A: Gen 2010;373:154-9.

[56] Furusawa T, Miura Y, Kori Y, Sato M, Suzuki N. The cycle usage test of Ni/MgO 
catalyst for the steam reforming of naphthalene/benzene as model tar compounds of biomass gasification. Catal Commun 2009;10:552-6.

[57] Ferella F, Stoehr J, Michelis ID, Hornung A. Zirconia and alumina based catalysts for steam reforming of naphthalene. Fuel 2013;105:614-29.

[58] Zhao B, Zhang X, Chen L, Qu R, Meng G, Yi X, et al. Steam reforming of toluene as model compound of biomass pyrolysis tar for hydrogen. Biomass Bioenergy 2010;34:140-4.

[59] Park HJ, Park SH, Sohn JM, Park J, Jeon JK, Kim SS, et al. Steam reforming of biomass gasification tar using benzene as a model compound over various $\mathrm{Ni}$ supported metal oxide catalysts. Bioresour Technol 2010;101:S101-3.

[60] Virginie M, Courson C, Kiennemann A. Toluene steam reforming as tar model molecule produced during biomass gasification with an iron/olivine catalyst. Comptes Rendus Chimie 2010;13:1319-25.

[61] Jess A. Mechanisms and kinetics of thermal reactions of aromatic hydrocarbons from pyrolysis of solid fuels. Fuel 1996;75,12:1441-8.

[62] Rama SR, Kawai S, Yamada H, Tagawa T. Preliminary assessment of oxidation pretreated Hastelloy as hydrocarbon steam reforming catalyst. J Catal 2014; Article ID 210371.

[63] Chen G, Zhang X, Mi Z. Effects of pressure on coke and formation of its precursors during catalytic cracking of toluene over USY catalyst. J Fuel Chem Technol 2007;35(2):211-6.

[64] Guan G, Hao X, Abudula A. Heterogeneous Catalysts from Natural Sources for Tar Removal: A Mini Review. J Adv Catal Sci Technol 2014; 1: 20-8.

[65] Kaewpanha M, Guan G, Hao X, Wang Z, Kasai Y, Kakuta S, Kusakabe K, 
Abudula A. Steam reforming of tar derived from the steam pyrolysis of biomass over metal catalyst supported on zeolite. J Taiwan Inst Chem Eng 2013; 44: 1022-6.

[66] Guan G, Kaewpanha M, Hao X, Wang Z, Cheng Y, Kasai Y, Abudula A. Promoting effect of potassium addition to calcined scallop shell supported catalysts for the decomposition of tar derived from different biomass resources. Fuel 2013; 109:241-7.

[67] Michel R, Rapagnà S, Marcello MD, Burg P, Matt M, Courson C, et al. Catalytic steam gasification of Miscanthus X giganteus in fluidised bed reactor on olivine based catalysts. Fuel Process Technol 2011;92:1169-77.

[68] Quitete CPB, Bittencourt RCP, Souza MMVM. Steam reforming of tar using toluene as a model compound with nickel catalysts supported on hexaaluminates. Appl Catal A: Gen 2014;478:234-40.

[69] Srinakruang J, Sato K, Vitidsant T, Fujimoto K. A highly efficient catalyst for tar gasification with steam. Catal Commun 2005;6:437-40.

[70] Wang TJ, Chang J, Wu CZ, Fu Y, Chen Y. The steam reforming of naphthalene over a nickel-dolomite cracking catalyst. Biomass Bioenergy 2005;28:508-14.

[71] Zhang R, Wang Y, Brown RC. Steam reforming of tar compounds over Ni/olivine catalysts doped with $\mathrm{CeO}_{2}$. Energy Conv Manag 2007;48:68-77.

[72] Ayabe S, Omoto H, Utaka T, Kikuchi R, Sasaki K, Teraoka Y, et al. Catalytic autothermal reforming of methane and propane over supported metal catalysts. Appl Catal A: Gen 2003;241:261-9.

[73] Hegarty MES, O'Connor AM, Ross JRH. Syngas production from natural gas using $\mathrm{ZrO}_{2}$-supported metals. Catal Today 1998;42:225-32. 
[74] Urasaki K, Tokunaga K, Sekine Y, Matsukata M, Kikuchi E. Production of hydrogen by steam reforming of ethanol over cobalt and nickel catalysts supported on perovskite-type oxides. Catal Commun 2008;9:600-4.

[75] $\mathrm{Hu} \mathrm{X}, \mathrm{Lu} \mathrm{G}$. Investigation of steam reforming of acetic acid to hydrogen over Ni-Co metal catalyst. J Mol Catal A: Chem 2007;261:43-8.

[76] He L, Berntsen H, Ochoa-Fernández E, Walmsley JC, Blekkan EA, Chen D. Co-Ni catalysts derived from hydrotalcite-like materials for hydrogen production by ethanol steam reforming. Topics in Catal 2009;52:206-17.

[77] Furusawa T, Saito K, Kori Y, Miura Y, Sato M, Suzuki N. Steam reforming of naphthalene/benzene with various types of Pt- and Ni-based catalysts for hydrogen production. Fuel 2013;103:111-21.

[78] Polychronopoulou K, Fierro JLG, Efstathiou AM. The phenol steam reforming reaction over MgO-based supported Rh catalysts. J Catal 2004;228:417-32.

[79] Tomishige K, Asadullah M, Kunimori K. Syngas production by biomass gasification using $\mathrm{Rh} / \mathrm{CeO}_{2} / \mathrm{SiO}_{2}$ catalysts and fluidized bed reactor. Catal Today 2004;89:389-403.

[80] Iida H, Noguchi K, Numa T, Igarashi A, Okumura K. Ru/12SrO-7 $\mathrm{Al}_{2} \mathrm{O}_{3}(\mathrm{~S} 12 \mathrm{~A} 7)$ catalyst prepared by physical mixing with $\mathrm{Ru}\left(\mathrm{PPh}_{3}\right)_{3} \mathrm{Cl}_{2}$ for steam reforming of toluene. Catal Commun 2015; 72: 101-4.

[81] Iida H, Onuki N, Numa T, Igarashi A. Steam reforming of dodecane and toluene over $\mathrm{Ru} / 12 \mathrm{SrO}-7 \mathrm{Al}_{2} \mathrm{O}_{3}(\mathrm{~S} 12 \mathrm{~A} 7)$ catalysts. Fuel Process Technol 2016; 142: $397-402$

[82] Ammendola P, Cammisa E, Chirone R, Lisi L, Ruoppolo G. Effect of sulphur on the performance of $\mathrm{Rh}-\mathrm{LaCoO}_{3}$ based catalyst for tar conversion to syngas. Appl 
Catal B: Environ 2012; 113-114:11-8.

[83] Constantinou DA, Efstathiou AM. Low-temperature purification of gas streams from phenol by steam reforming over novel supported-Rh catalysts. Appl Catal B: Environ 2010; 96:276-89.

[84] Polychronopoulou K, Bakandritsos A, Tzitzios V, Fierro JLG, Efstathiou AM. Absorption-enhanced reforming of phenol by steam over supported Fe catalysts. J Catal 2006;241:132-48.

[85] Duman G, Watanabe T, Uddin MA, Yanik J. Steam gasification of safflower seed cake and catalytic tar decomposition over ceria modified iron oxide catalysts. Fuel Process Technol 2014;126:276-83.

[86] Wang L, Li D, Koike M, Koso S, Nakagawa Y, Xu Y, et al. Catalytic performance and characterization of $\mathrm{Ni}-\mathrm{Fe}$ catalysts for the steam reforming of tar from biomass pyrolysis to synthesis gas. Appl Catal A: Gen 2011;392:248-55.

[87] Wang L, Hisada Y, Koike M, Li D, Watanabe H, Nakagawa Y, et al. Catalyst property of Co-Fe alloy particles in the steam reforming of biomass tar and toluene. Appl Catal B: Environ 2012; 121-122:95-104.

[88] Mitsuoka K, Hayashi S, Amano H, Kayahara K, Sasaoaka E, Uddin MA. Gasification of woody biomass char with $\mathrm{CO}_{2}$ : The catalytic effects of $\mathrm{K}$ and $\mathrm{Ca}$ species on char gasification reactivity. Fuel Process Technol 2011;92:26-31.

[89] Kuchonthara P, Vitidsant T, Tsutsumi A. Catalytic effects of potassium on lignin steam gasification with $\gamma-\mathrm{Al}_{2} \mathrm{O}_{3}$ as a bed material. Korean $\mathrm{J}$ Chem Eng 2008;25:656-62.

[90] Hognon C, Dupont C, Grateau M, Delrue F. Comparison of steam gasification reactivity of algal and lignocellulosic biomass: Influence of inorganic elements. 
Bioresour Technol 2014;164:347-53.

[91] Howaniec N, Adam Smoliński. Effect of fuel blend composition on the efficiency of hydrogen-rich gas production in co-gasification of coal and biomass. Fuel 2014;128:442-50.

[92] Rizkiana J, Guan G, Widayatno WB, Hao X, Huang W, Abudula A. Promoting effect of various biomass ashes on the steam gasification of low-rank coal. Appl Energy 2014; 133:282-8.

[93] Rizkiana J, Guan G, Widayatno WB, Hao X, Huang W, Tsutsumi A, Abudula A. Effect of biomass type on the performance of cogasification of low rank coal with biomass at relatively low temperatures. Fuel 2014;134: 414-9.

[94] Lahijani P, Zainal ZA, Mohamed AR, Mohammadi M. Ash of palm empty fruit bunch as a natural catalyst for promoting the $\mathrm{CO}_{2}$ gasification reactivity of biomass char. Bioresour Technol 2013; 132: 351-5.

[95] Kuhn JN, Zhao Z, Felix LG, Slimane RB, Choi CW, Ozkan US. Olivine catalysts for methane- and tar-steam reforming. Appl Catal B: Environ 2008;81:14-26.

[96] Constantinou DA, Fierro JLG, Efstathiou AM. A comparative study of the steam reforming of phenol towards $\mathrm{H}_{2}$ production over natural calcite, dolomite and olivine materials. Appl Catal B: Environ 2010;95:255-69.

[97] Myrén C, Hörnell C, Björnbom E, Sjöström K. Catalytic tar decomposition of biomass pyrolysis gas with a combination of dolomite and silica. Biomass Bioenergy 2002;23:217-27.

[98] Devi L, Ptasinski KJ, Janssen FJJG, Paasen SVB, Bergman PCA, Kiel JHA. Catalytic decomposition of biomass tars: use of dolomite and untreated olivine. Renew Energy 2005;30:565-87. 
[99] Hu G, Xu S, Li S, Xiao C, Liu S. Steam gasification of apricot stones with olivine and dolomite as downstream catalysts. Fuel Process Technol 2006;87:375-82.

[100] Roche E, Andrés JM, Narros A, Rodríguez ME. Air and air-steam gasification of sewage sludge. The influence of dolomite and throughput in tar production and composition. Fuel 2014;115:54-61.

[101] Fredriksson HOA, Lancee RJ, Thüne PC, Veringa HJ, Niemantsverdriet JW. Olivine as tar removal catalyst in biomass gasification: Catalyst dynamics under model conditions. Appl Catal B: Environ 2013;130-131:168-77.

[102] Christodoulou C, Grimekis D, Panopoulos KD, Pachatouridou EP, Iliopoulou EF, Kakaras E. Comparing calcined and un-treated olivine as bed materials for tar reduction in fluidized bed gasification. Fuel Process Technol 2014;124:275-85.

[103] Michel R, Łamacz A, Krzton A, Djéga-Mariadassou G, Burg P, Courson C, et al. Steam reforming of a-methylnaphthalene as a model tar compound over olivine and olivine supported nickel. Fuel 2013;109:653-60.

[104] Virginie M, Courson C, Niznansky D, Chaoui N, Kiennemann A. Characterization and reactivity in toluene reforming of a Fe/olivine catalyst designed for gas cleanup in biomass gasification. Appl Catal B: Environ 2010;101:90-100.

[105] Yang X, Xu S, Xu H, Liu X, Liu C. Nickel supported on modified olivine catalysts for steam reforming of biomass gasification tar. Catal Commun 2010;11:383-6.

[106] Corma A. State of the art and future challenges of zeolites as catalysts. J Catal 2003;216:298-312.

[107] Anis S, Zainal ZA. Tar reduction in biomass producer gas via mechanical, 
catalytic and thermal methods: A review. Renew Sustain Energy Rev 2011;15:2355-77.

[108] Velegol D, Gautam M, Shamsi A. Catalytic cracking of a coal tar in a fluid bed reactor. Powder Technol 1997;93:93-100.

[109] Radwan AM, Kyotani T, Tomita A. Characterization of coke deposited from cracking of benzene over USY zeolite catalyst. Appl Catal A: Gen 2000;192:43-50.

[110] Wu C, Williams PT. Ni/CeO $/ 2 \mathrm{ZSM}-5$ catalysts for the production of hydrogen from the pyrolysis-gasification of polypropylene. Int $\mathbf{J}$ Hydrogen Energy $2009 ; 34: 6242-52$.

[111] Dou B, Gao J, Sha X, Baek SW. Catalytic cracking of tar component from high-temperature fuel gas. Appl Therm Eng 2003;23:2229-39.

[112] Buchireddy PR, Bricka RM, Rodriguez J, Holmes W. Biomass gasification: catalytic removal of tars over zeolites and nickel supported zeolites. Energy Fuel 2010;24:2707-15.

[113] Wang Y, Hu X, Song Y, Min Z, Mourant D, Li T, et al. Catalytic steam reforming of cellulose-derived compounds using a char-supported iron catalyst. Fuel Process Technol 2013;116:234-40.

[114] Wang FJ, Zhang S, Chen ZD, Liu C, Wang YG. Tar reforming using char as catalyst during pyrolysis and gasification of Shengli brown coal. J Anal Appl Pyrolysis 2014;105:269-75.

[115] Wang D, Yuan W, Ji W. Char and char-supported nickel catalysts for secondary syngas cleanup and conditioning. Appl Energy 2011;88:1656-63.

[116] Zhang S, Asadullah M, Dong L, Tay HL, Li CZ. An advanced biomass 
gasification technology with integrated catalytic hot gas cleaning. Part II: Tar reforming using char as a catalyst or as a catalyst support. Fuel 2013;112:646-53.

[117] Min Z, Yimsiri P, Asadullah M, Zhang S, Li CZ. Catalytic reforming of tar during gasification. Part II. Char as a catalyst or as a catalyst support for tar reforming. Fuel 2011;90:2545-52.

[118] Bhandari PN, Kumar A, Bellmer DD, Huhnke RL. Synthesis and evaluation of biochar-derived catalysts for removal of toluene (model tar) from biomass-generated producer gas. Renew Energy 2014;66:346-53.

[119] Milne TA, Abatzoglou N, Evans RJ. Biomass gasifier 'tars`: their nature, formation and conversion. NREL/TP-570-25357, National Renewable Energy Laboratory; 1998.

[120] Coll R, Salvado J, Farriol X, Montane D. Steam reforming model compounds of biomass gasification tars: conversion at different operating conditions and tendency towards coke formation. Fuel Process Technol 2001; 74: 19-31.

[121] M Kaewpanha. Catalytic steam reforming of biomass tar at low temperatures. $\mathrm{PhD}$ dissertation, Hirosaki University, Japan, 2015.

\section{Figure captions}

Fig. 1. Major groups of biomass and their sub classifications [2,7].

Fig. 2. Four possible routes for biomass energy conversion [1-9].

Fig. 3. Main processes during biomass gasification. 
Fig. 4 Tar maturation scheme (Modified from Elliott 1988) [44].

Fig. 5. Typical composition of biomass tars $[48,120]$.

Fig. 6. Simplified reaction scheme of thermal conversion of aromatic hydrocarbons in the presence of hydrogen and steam (Modified from Jess 1996) [61].

Fig. 7. Mechanism of catalytic steam reforming of biomass derived tar supposed in our study $\left(\mathrm{M}_{\mathrm{x}} \mathrm{O}_{\mathrm{y}}\right.$ represents metal oxide catalyst)[121].

\section{Table captions}

Table 1. World primary energy demand (Mtoe) [8].

Table 2. Tar classification based on its appearance $[45,98,119]$.

Table 3. Tar classification based on molecular weight of tar compounds $[33,98]$.

Table 4. Typical catalysts for tar reforming reported in the literature. 


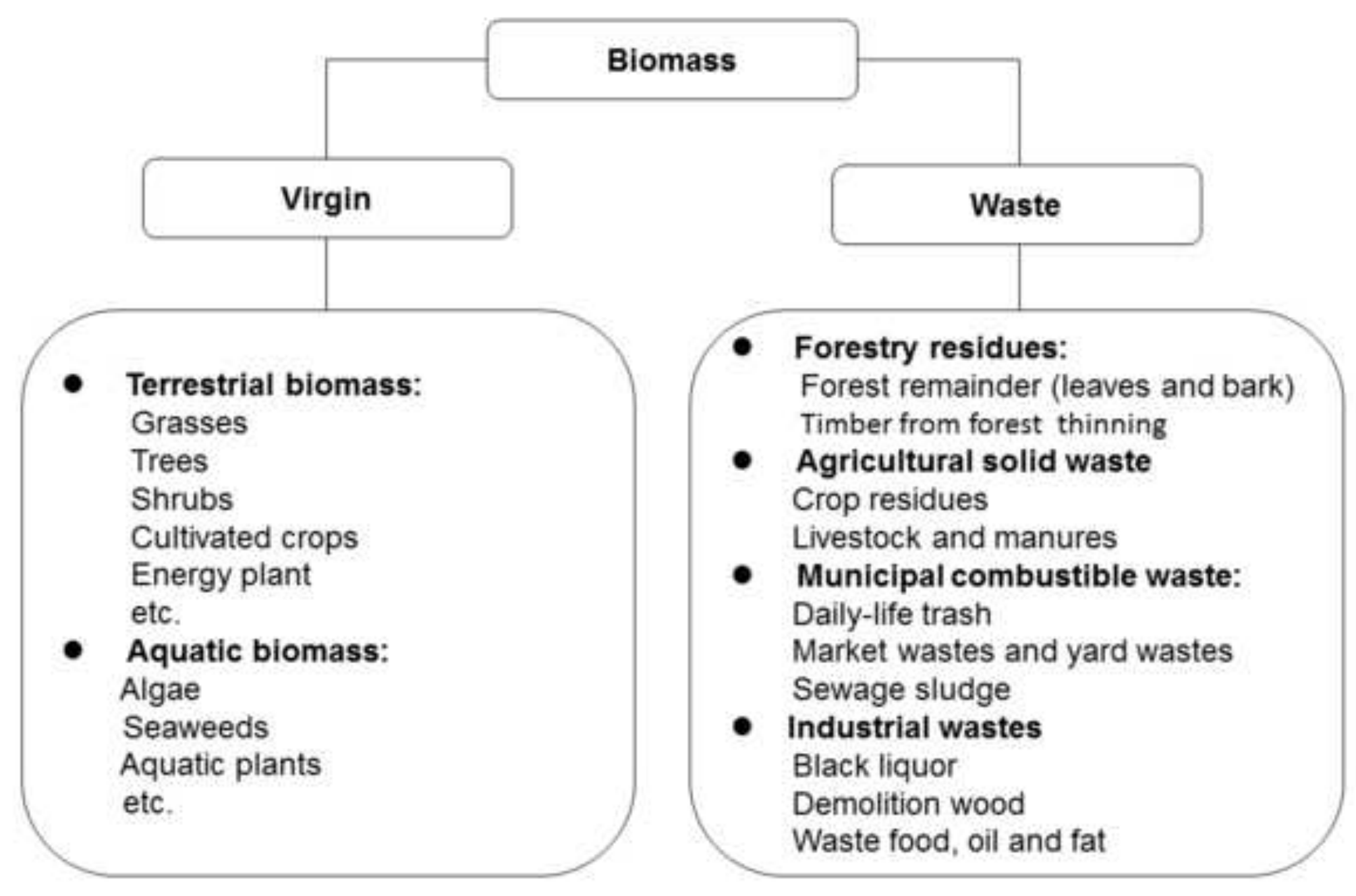




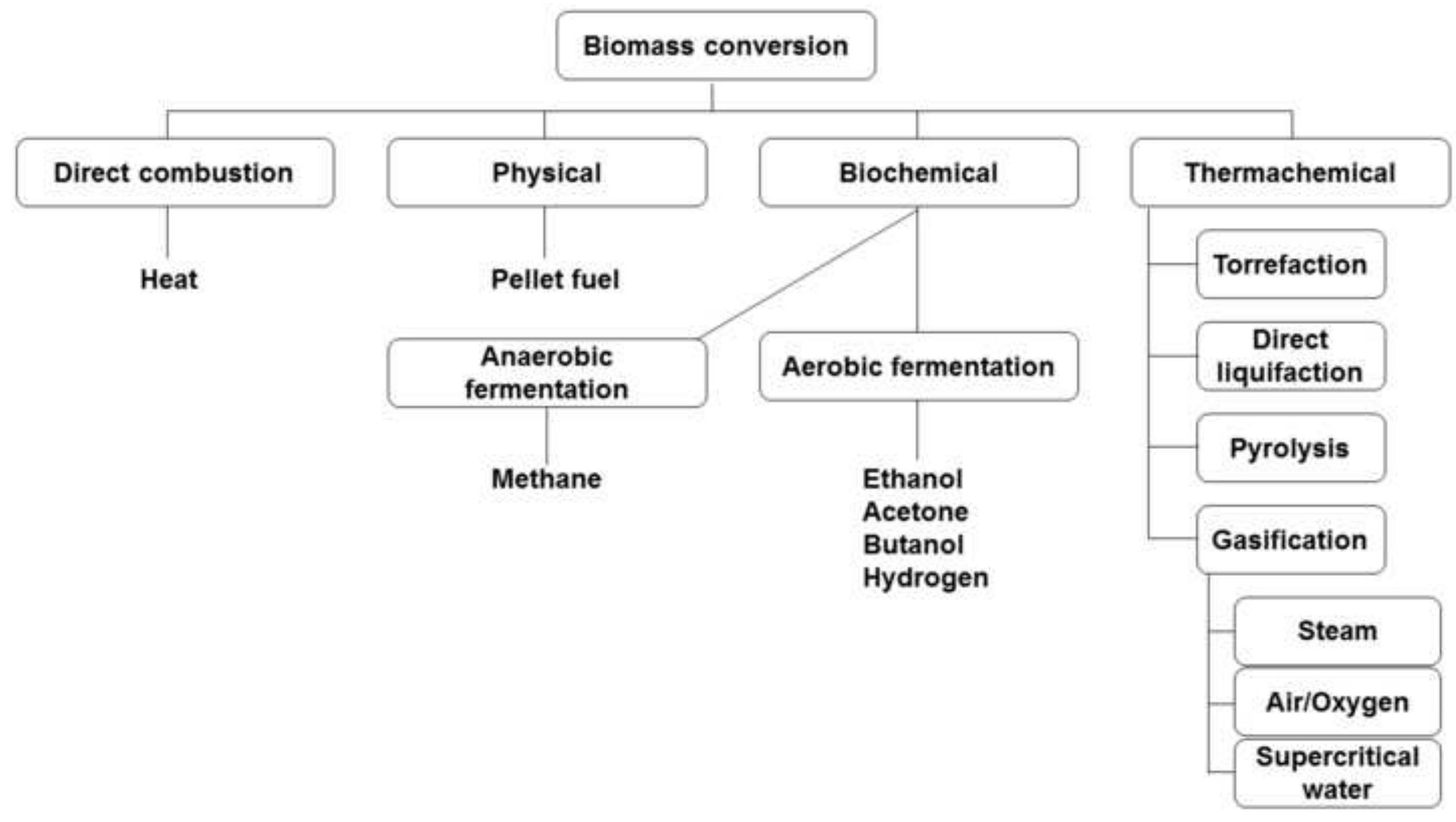




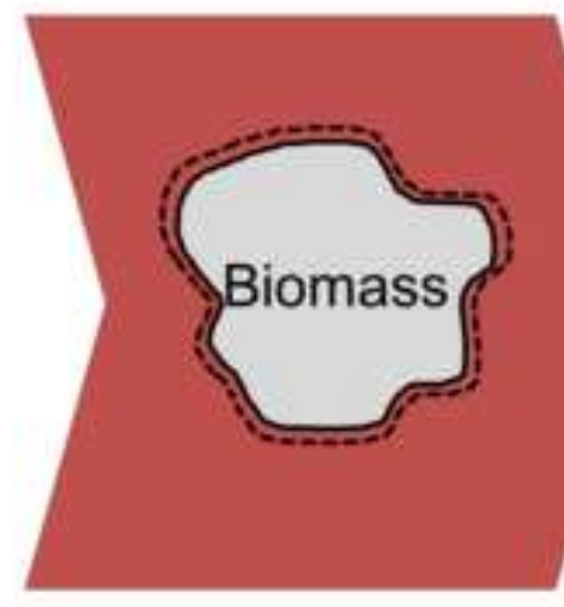

Heating and drying

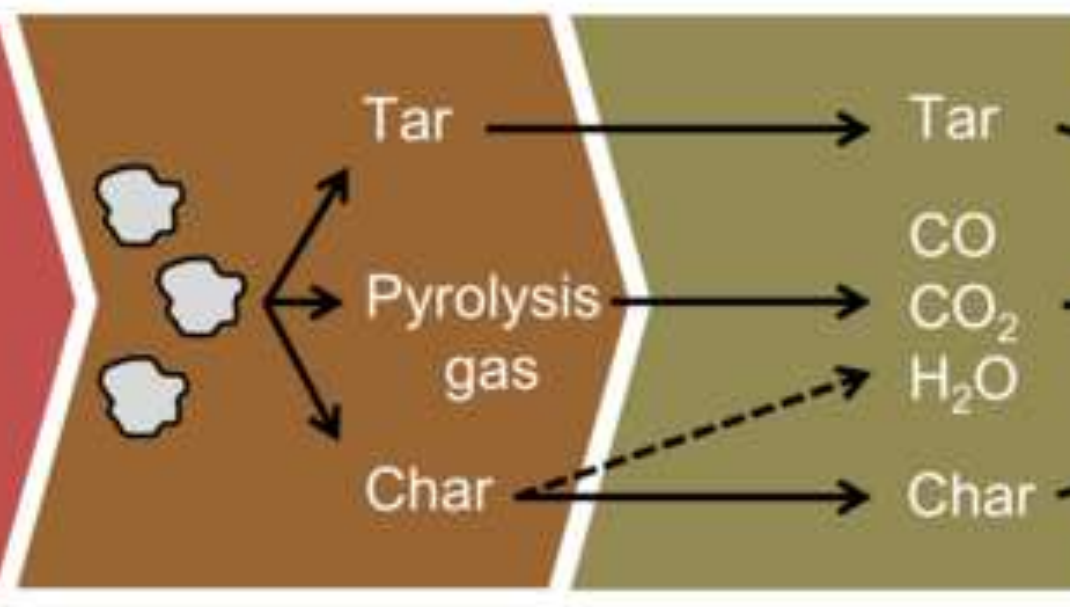

Pyrolysis
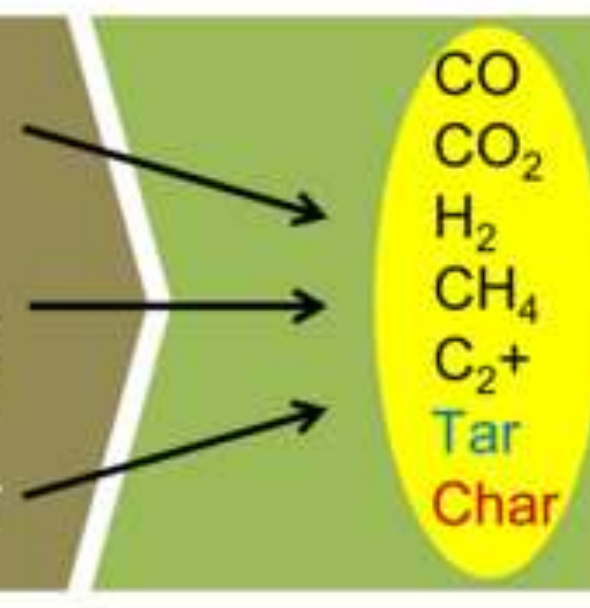

Oxidation
Gasification 
Mixed oxygenates $400{ }^{\circ} \mathrm{C}$

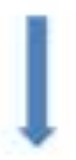

Phenolic ethers $500{ }^{\circ} \mathrm{C}$

Alkyl phenolics $600{ }^{\circ} \mathrm{C}$

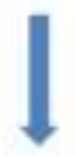

Heterocyclic oxygenates $700{ }^{\circ} \mathrm{C}$
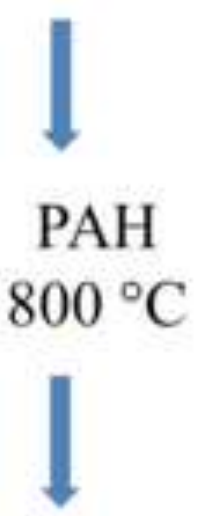

Larger PAH $900{ }^{\circ} \mathrm{C}$

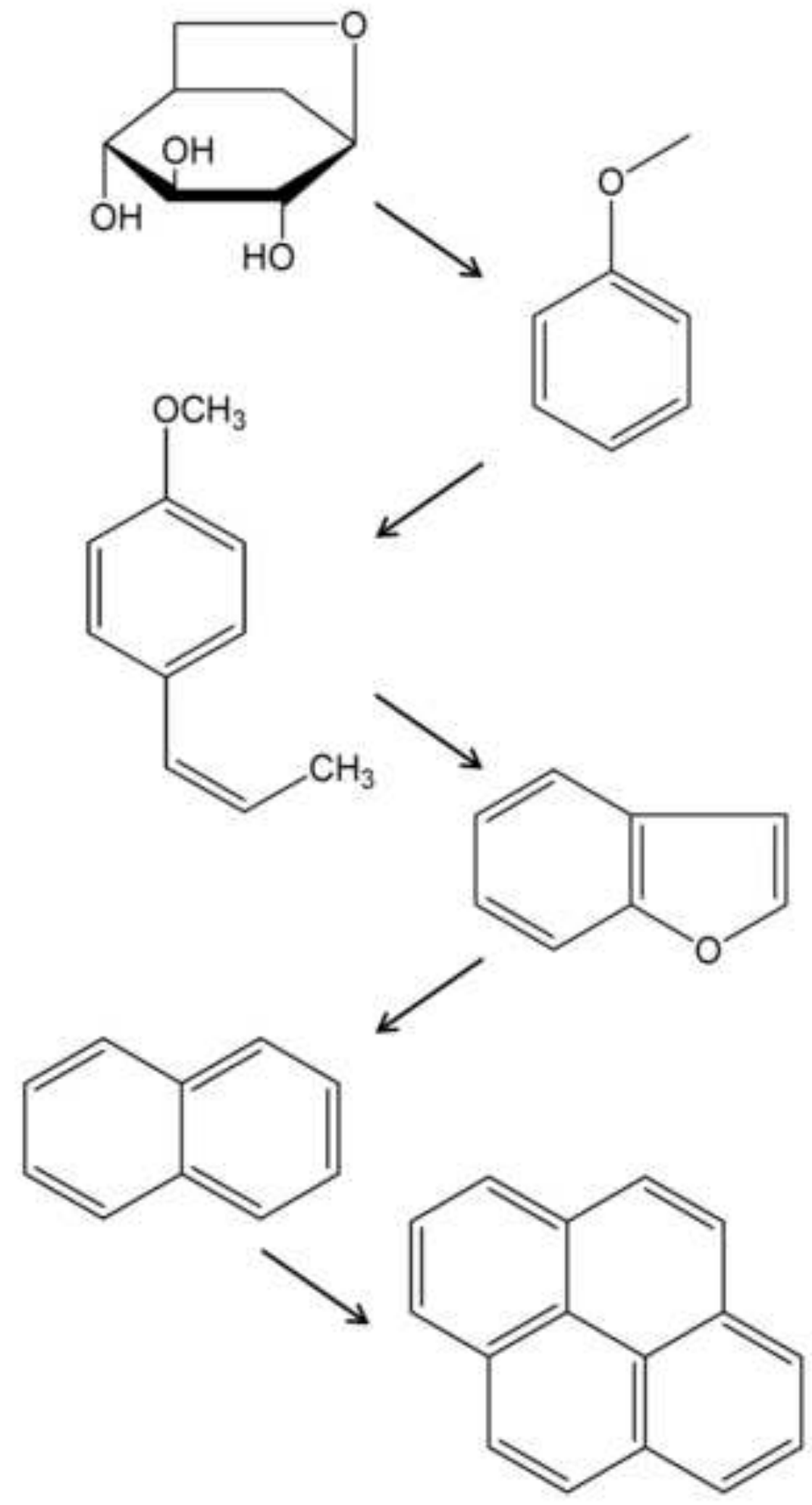




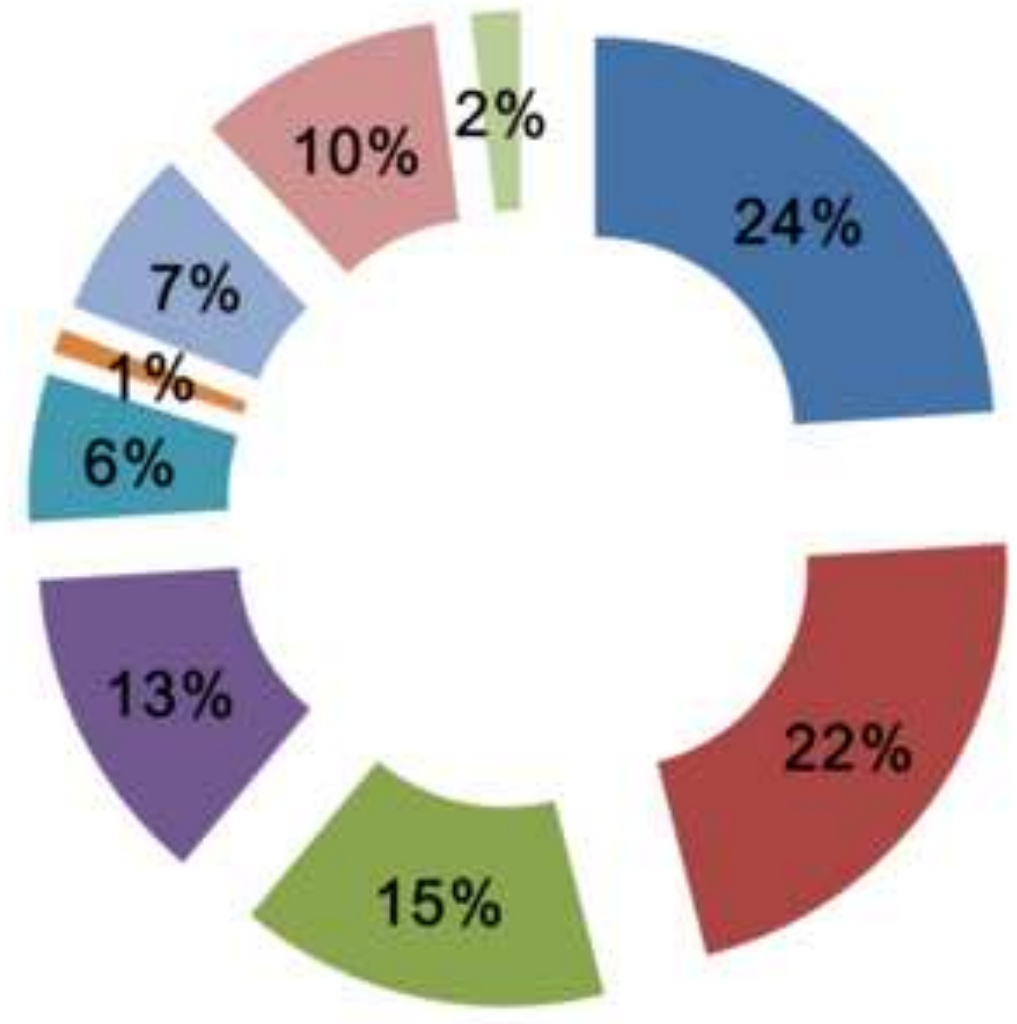

- Toluene

- Other one ring aromatic Hydrocarbons

- Naphthalene

= Other two ring aromatic Hydrocarbons

- Three ring aromatic Hydrocarbons

a Four ring aromatic Hydrocarbons

Ehenolic compounds

weterocyclic compounds

m Others 


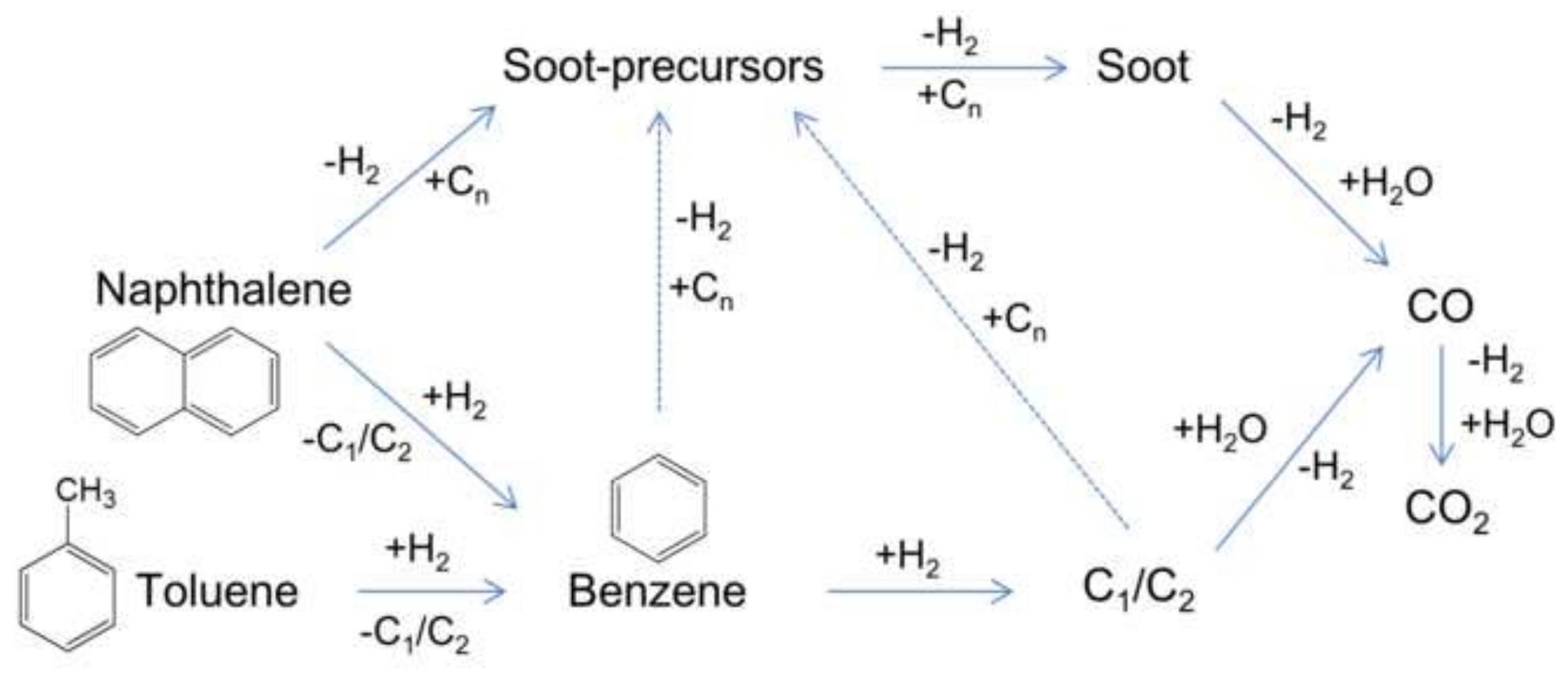


Table 1. World primary energy demand by fuel (Mtoe) [8].

\begin{tabular}{lrrrrrrc}
\hline & 1980 & 2009 & 2015 & 2020 & 2030 & 2035 & $2009-2035^{\text {a }}$ \\
\hline Coal & 1792 & 3294 & 3944 & 4083 & 4099 & 4101 & $0.8 \%$ \\
Oil & 3097 & 3987 & 4322 & 4384 & 4546 & 4645 & $0.6 \%$ \\
Gas & 1234 & 2539 & 2945 & 3214 & 3698 & 3928 & $1.7 \%$ \\
Nuclear & 186 & 703 & 796 & 929 & 1128 & 1212 & $2.1 \%$ \\
Hydro & 148 & 280 & 334 & 377 & 450 & 475 & $2.1 \%$ \\
Biomass and waste & 749 & 1230 & 1375 & 1495 & 1761 & 1911 & $1.7 \%$ \\
Other renewables & 12 & 99 & 197 & 287 & 524 & 690 & $7.8 \%$ \\
\hline Total & 7219 & 12132 & 13913 & 14769 & 16206 & 16961 & $1.3 \%$ \\
\hline
\end{tabular}

${ }^{\mathrm{a}}$ Compound average annual growth rate. 
Table 2. Tar classification based on its appearance $[45,98,119]$.

\begin{tabular}{ll}
\hline Tar class & Property \\
\hline Primary & Low molecular weight oxygenated hydrocarbons such as \\
& $\begin{array}{l}\text { levoglucosan, furfural and hydroxyacetaldehyde, produced at } \\
\end{array}$ \\
& $400-700{ }^{\circ} \mathrm{C}$ \\
Secondary & Phenolic and olefin compounds such phenol, cresol and xylene, \\
& produced at around $700-850{ }^{\circ} \mathrm{C}$ \\
Tertiary & Complex aromatic compounds such as benzene, naphthalene, \\
& pyrene and toluene, produced at around $850-1000{ }^{\circ} \mathrm{C}$
\end{tabular}


Table 3. Tar classification based on molecular weight of tar compounds $[33,98]$.

\begin{tabular}{ll}
\hline Tar class & Property \\
\hline Class 1 & GC undetectable heaviest tars which condense at high temperature \\
& and very low concentration \\
Class 2 & Heterocyclic aromatic compounds which are high water solubility \\
& such as pyridine, phenol, cresols, quinoline, isoquinoline and \\
& dibenzophenol \\
Class 3 & Light hydrocarbon aromatic compounds (1 ring) which do not cause \\
& a problem regarding condensability and solubility such as toluene, \\
& ethylbenzene, xylenes, styrene \\
Class 4 & Light polyaromatic hydrocarbon compounds (2-3 rings) which \\
& condense at low temperature even at very low concentration such as \\
& indene, naphthalene, methylnaphthalene, biphenyl, acenaphthalene, \\
& fluorene, phenanthrene, anthracene \\
& Heavy polyaromatic hydrocarbon compounds (4-7 rings) which \\
& condense at high temperature at low concentration such as \\
& fluoranthene, pyrene, chrysene, perylene, coronene \\
Class 5 &
\end{tabular}


Table 4. Typical catalysts for tar reforming reported in the literature.

\begin{tabular}{|c|c|c|c|}
\hline Catalyst & Tar & Properties & Ref \\
\hline Ni/olivine & Toluene & $\begin{array}{l}\text { The presence of } \mathrm{Ni}-\mathrm{Fe} \text { alloys and basic } \mathrm{MgO} \\
\text { oxide in olivine are beneficial for limiting } \\
\text { carbon formation }\end{array}$ & [10] \\
\hline $\mathrm{Ni} /$ olivine- $\mathrm{CeO}_{2}$ & $\begin{array}{l}\text { Benzene } \\
\text { Toluene }\end{array}$ & $\begin{array}{l}3.0 \% \mathrm{NiO} / \text { olivine doped with } 1.0 \% \mathrm{CeO}_{2} \text { is } \\
\text { the most promising catalyst based on catalytic } \\
\text { activity and its resistance to coking. }\end{array}$ & [71] \\
\hline Ni-Co alloy & Acetic acid & $\begin{array}{l}\text { At the molar ratios of } 0.25: 1 \text { (Ni:Co), the } \\
\text { catalyst showed the best performances for } \\
\text { acetic acid steam reforming }\end{array}$ & [75] \\
\hline $\mathrm{Ni}-\mathrm{Co} / \mathrm{HT}$ & Ethanol & $\begin{array}{l}\text { The best catalytic performance is obtained } \\
\text { with the } 30 \mathrm{Co}-10 \mathrm{Ni} \text { catalyst, in which Co } \\
\text { and Ni are intimately mixed and dispersed in } \\
\text { hydrotalcite (HT)-like materials }\end{array}$ & [76] \\
\hline $\mathrm{Ru} / 12 \mathrm{SrO}-7 \mathrm{Al}_{2} \mathrm{O}_{3}$ & & $\mathrm{Ru} / \mathrm{SrO}-\mathrm{Al}_{2} \mathrm{O}_{3}$ catalysts with $12 \mathrm{SrO}-7 \mathrm{Al}_{2} \mathrm{O}_{3}$ & \\
\hline & Toluene & $\begin{array}{l}\text { phase exhibit superior catalytic activities } \\
\text { compared to a commercial } \mathrm{Ru} / \mathrm{Al}_{2} \mathrm{O}_{3} \text { catalyst, } \\
\text { despite low } \mathrm{Ru} \text { loading and } \mathrm{Ru} \text { dispersion. }\end{array}$ & [81] \\
\hline $\mathrm{Rh} / \mathrm{Ce}_{0.14} \mathrm{Zr}_{0.81} \mathrm{Mg}_{0.05} \mathrm{O}_{2}$ & Phenol & $\begin{array}{l}\text { A } 0.5 \mathrm{wt} \% \mathrm{Rh} / \mathrm{Ce}_{0.14} \mathrm{Zr}_{0.81} \mathrm{Mg}_{0.05} \mathrm{O}_{2} \text { catalyst } \\
\text { developed led to a significantly better } \\
\text { performance towards steam reforming of } \\
\text { phenol }\end{array}$ & [83] \\
\hline $\mathrm{Co} / \mathrm{MgO}$ & Phenol & $\begin{array}{l}12 \mathrm{wt} . \% \mathrm{Co} / \mathrm{MgO} \text { catalyst has higher activity } \\
\text { than any kinds of } \mathrm{Ni} / \mathrm{MgO} \text { catalysts }\end{array}$ & [12] \\
\hline $\mathrm{Co}-\mathrm{Fe} / \mathrm{Al}_{2} \mathrm{O}_{3}$ & $\begin{array}{l}\text { Biomass tar } \\
\text { Toluene }\end{array}$ & $\begin{array}{l}\mathrm{Co}-\mathrm{Fe} / \mathrm{Al}_{2} \mathrm{O}_{3} \text { catalysts with the optimum } \\
\text { composition }(\mathrm{Fe} / \mathrm{Co}=0.25) \text { is much higher } \\
\text { than corresponding monometallic Co and } \mathrm{Fe} \\
\text { catalysts in the steam reforming of tar from } \\
\text { the pyrolysis of cedar wood }\end{array}$ & \\
\hline $\mathrm{K}_{2} \mathrm{CO}_{3}$ & Biomass tar & $\begin{array}{l}\text { Almost all components in biomass are } \\
\text { completely converted at } 800^{\circ} \mathrm{C}\end{array}$ & [89] \\
\hline Calcined scallop shell & Biomass tar & $\begin{array}{l}\text { Calcined scallop shell (CS) as well as iron- or } \\
\text { nickel-loaded CS shows good catalytic } \\
\text { activity for tar reforming }\end{array}$ & $\begin{array}{l}{[39]} \\
{[42]}\end{array}$ \\
\hline Y-zeolite & Naphthalene & $\begin{array}{l}\text { Y-zeolite and nickel-supported Y-zeolite have } \\
\text { high catalytic activity for naphthalene } \\
\text { conversion }\end{array}$ & $\begin{array}{l}{[111]} \\
{[112]}\end{array}$ \\
\hline \multirow[t]{2}{*}{ Biomass char } & Biomass tar & $\begin{array}{l}\text { The char-supported iron/nickel catalysts have } \\
\text { high activity for the reforming of tar }\end{array}$ & $\begin{array}{l}{[116]} \\
{[117]}\end{array}$ \\
\hline & & & [118] \\
\hline
\end{tabular}

